\title{
Presence of multi-drug resistant pathogenic Escherichia coli in the San Pedro River located in the State of Aguascalientes, Mexico
}

\section{Flor Y. Ramírez Castillo' ${ }^{1}$, Francisco J. Avelar González² , Philippe Garneau ${ }^{3}$, Francisco Márquez Díaz ${ }^{4}$, Alma L. Guerrero Barrera ${ }^{1 *}$ and Josée Harel ${ }^{3 *}$}

\author{
'Laboratorio de Biología Celular y Tisular, Departamento de Morfología, Centro de Ciencias Básicas, Universidad Autónoma de Aguascalientes, \\ Aguascalientes, México \\ ${ }^{2}$ Laboratorio de Ciencias Ambientales, Departamento de Fisiología y Farmacología, Centro de Ciencias Básicas, Universidad Autónoma de Aguascalientes, \\ Aguascalientes, México \\ ${ }^{3}$ Faculté de Médecine Vétérinaire, Centre de Recherche en Infectiologie Porcine, Université de Montréal, St-Hyacinthe, QC, Canada \\ ${ }^{4}$ Departamento de Infectología, Centenario Hospital Miguel Hidalgo, Aguascalientes, México
}

\section{Edited by:}

Axel Cloeckaert, Institut National de la Recherche Agronomique, France

Reviewed by:

Charles W. Knapp, University of

Strathclyde, UK

Etienne Giraud, Institut National de la Recherche Agronomique, France

\section{*Correspondence:}

Josée Harel, Faculté de Médecine Vétérinaire, Centre de Recherche en Infectiologie Porcine, Université de Montréal, 3200, rue Sicotte,

St-Hyacinthe, OC J2S 2M2, Canada e-mail: josee.harel@umontreal.ca;

Alma L. Guerrero Barrera, Centro de Ciencias Básicas, Universidad

Autónoma de Aguascalientes, Av. Universidad 940, Col. Ciudad Universitaria, Aguascalientes, C.P. 20131, Mexico e-mail: alguerre@correo.uaa.mx
Contamination of surface waters in developing countries is a great concern. Treated and untreated wastewaters have been discharged into rivers and streams, leading to possible waterborne infection outbreaks and may represent a significant dissemination mechanism of antibiotic resistance genes. In this study, the water quality of San Pedro River, the main river and pluvial collector of the Aguascalientes State, Mexico was assessed. Thirty sample locations were tested throughout the River. The main physicochemical parameters of water were evaluated. Results showed high levels of fecal pollution as well as inorganic and organic matter abundant enough to support the heterotrophic growth of microorganisms. These results indicate poor water quality in samples from different locations. One hundred and fifty Escherichia coli were collected and screened by PCR for several virulence genes. Isolates were classified as either pathogenic $(n=91)$ or commensal $(n=59)$. The disc diffusion method was used to determine antimicrobial susceptibility to 13 antibiotics. Fifty-two percent of the isolates were resistant to at least one antimicrobial agent and $30.6 \%$ were multi-resistant. Eighteen E. coli strains were quinolone resistant of which 16 were multi-resistant. Plasmid-mediated quinolone resistance (PMQR) genes were detected in 12 isolates. Mutations at the Ser-83 $\rightarrow$ Leu and/or Asp-87 $\rightarrow$ Asn in the gyrA gene were detected as well as mutations at the Ser-80 $\rightarrow$ lle in parC. An E. coli microarray (Maxivirulence $V$ 3.1) was used to characterize the virulence and antimicrobial resistance genes profiles of the fluoroquinolone-resistant isolates. Antimicrobial resistance genes such as blaTEM, sull, sulll, dhfrlX, aph3 (strA), and tet $(\mathrm{B})$ as well as integrons were found in fluoroquinolone (FQ) resistance E. coli strains. The presence of potential pathogenic E. coli and antibiotic resistance in San Pedro River such as $\mathrm{FQ}$ resistant $E$. coli could pose a potential threat to human and animal health.

Keywords: water quality, antibiotic resistance, fluoroquinolone, virulence factors, pathogenic Escherichia coli

\section{INTRODUCTION}

Escherichia coli is a commensal member of the intestinal flora of humans and warm-blooded animals. Several genotypes have acquired specific virulence factors and are capable of causing disease as gastrointestinal diseases, urinary tract infections (UTIs) and sepsis/meningitis. Intestinal pathogenic strains causing diarrhea include enteropathogenic E. coli (EPEC), enterohemorragic E. coli (EHEC), enterotoxigenic E. coli (ETEC), enteroaggregative E. coli (EAEC), enteroinvasive E. coli (EIEC) and diffusely adherent E. coli (DAEC, Nataro and Kaper, 1998). The extraintestinal pathogenic E. coli (ExPEC) group is composed of uropathogenic E. coli (UPEC), which is the main causes of UTIs, meningitisassociated E. coli (MNEC), sepsis-associated E. coli (SEPEC) and the avian pathogenic E. coli (APEC), which is associated with respiratory infections, pericarditis, and septicaemia in poultry (Kaper et al., 2004).

The presence of $E$. coli in water is widely used as a microbiological indicator of fecal pollution and water quality (WHO, 2006). The presence of pathogenic E. coli in environmental water creates a potential risk for infections in humans and animals especially since water is used for irrigation, a source of drinking water, and for recreational purposes (Hamelin et al., 2006, 2007; Kümmerer, 2009a; Koczura et al., 2012). Furthermore, the presence of antimicrobial resistant bacteria in the environment is another great concern for public health.

The contamination of aquatic and soil environments by untreated sewage or manure coming from human or animals treated with antibiotics (Baquero et al., 2008; Kümmerer, 2009b; 
Lupo et al., 2012; Suzuki and Hoa, 2012), as well as the presence of heavy metal pollution (McArthur and Tuckfield, 2000) and quaternary ammonium compounds (QACs; Hegstad et al., 2010) might result in the presence of antimicrobial resistant bacteria. Furthermore, most antibiotics are not fully eliminated during the sewage treatment process. Thus, an aquatic environment such as rivers or streams could act as an antibiotic resistant genes reservoir and facilitate the dissemination of these genes (Kümmerer, 2004; Lupo et al., 2012). The emergence of antimicrobial resistance mechanisms, especially those associated with mobile genetic elements, may enhances the possibility that virulence factors genes and antibiotic resistance genes are spread simultaneously, inducing the emergence of new pathogens (Chen et al., 2011; Da Silva and Mendoça, 2012; Koczura et al., 2012).

Fluoroquinolone (FQ) is a family of widely used synthetic antimicrobial agents with a broad antibacterial spectrum that is used as a front line drug for urinary tract and intestinal infections. However, increase in the prevalence of FQ resistant bacteria has been a great concern worldwide in the last years. Several mechanisms have been described for FQ resistance. In E. coli, the resistance is primarily associated with the accumulation of mutations in the quinolone-resistance determining regions (QRDRs) of gyrA and parC, which encode topoisomerase II (DNA gyrase) and topoisomerase IV respectively (Hooper, 2001; Hopkins et al., 2005). These mutations can lead to conformational changes in the enzymes and thus preventing quinolones from binding to the DNA-substrate complex (Tran et al., 2005a,b). In addition, several other mechanisms can contribute to FQ resistance, including plasmid-mediated quinolone resistance (PMQR) determinants (Martinez-Martinez et al., 1998), such as the Qnr protein (QnrA, QnrB, QnrC, QnrD, and $\mathrm{QnrS}$ ), the variant of the aminoglycoside-modifying enzyme, AAC $\left(6^{\prime}\right)$-Ib-cr (Robicsek et al., 2006a), and the efflux pumps QepA (Yamane et al., 2007), and OqxAB (Hansen et al., 2004; Jacoby, 2005).

Pollution of surface waters may represent a pathway for the global dissemination of antibiotic resistance (Chen et al., 2011). Water contamination is a major environmental problem in Mexico. In the last decades, treated, and untreated wastewater have been released into natural streams leading to possible waterborne disease outbreaks resulting from the use of unsafe water for consumption, irrigation or recreational activities (Mazari-Hiriart et al., 2008; Chávez et al., 2011). Several studies on antibiotic resistant bacteria release and their occurrence in sewage and natural environments have been conducted (Sayah et al., 2005; Amábile-Cuevas et al., 2010; Chen et al., 2011; West et al., 2011; Czekalski et al., 2012; Sun et al., 2012; Tacão et al., 2012). However, the significance of rivers as environments providing irrigation water and recreational activities as well as the possibility of the potential spread of pathogenic and antibiotic resistant bacteria between the environment and humans and animals, marks them as highly relevant study subjects (Czekalski et al., 2012). In addition, anthropogenic activities might impact on water environment promoting the dissemination of antibiotic resistance (Pruden et al., 2006; Martinez, 2009; Tacão et al., 2012). Thus, it is of major importance to study how human activities can impact antimicrobial resistant bacteria and antimicrobial resistance genes in the environment in order to understand their spread and health implications (Tacão et al., 2012).

In this study, the water quality of San Pedro River of Aguascalientes State in Mexico was evaluated. Currently, the river is being contaminated by wastewater from urban municipal sewers, industrial activities, and livestock farms. The objectives of this study were to evaluate the quality of the water between sample locations in the river polluted by different human activities, to determine the presence of pathogenic E. coli and assess the antimicrobial resistance profiles for the $E$. coli isolates, focusing in FQs agents.

\section{MATERIALS AND METHODS WATER SAMPLING AND E. coli ISOLATION}

Thirty sample locations were selected throughout San Pedro River and its main tributaries (Figure 1). All locations were sampled once and selected due to the presence of important discharges of treated or untreated wastewater into the river (Table 1). San Pedro River is the main watershed and pluvial collector of Aguascalientes State. The river belongs to the hydrological region of Lerma-Santiago-Pacifico which is one of the most important drainage basin of Mexico $\left(77,000 \mathrm{~km}^{2}\right)$, draining $80 \%$ of the Aguascalientes State. Currently, the San Pedro River is being contaminated by the influx of wastewater from population centers, industrial activities, agricultural activities, and livestock which results in different levels of surface water quality. It is estimated that $\sim 60 \%$ of the sewage water is discharged into the river without prior treatment (CONABIO, 2008). Nevertheless, the river is still used as important source for agricultural irrigation as well as recreational purposes in the cleanest zones (Gúzman-Colis et al., 2011).

Sampling was performed from June to November according to procedure described by the American Public Health Association (APHA, 1998) and the World Health Organization (WHO, 2006; Table 1). Water samples were collected in $180 \mathrm{~mL}$ sterile glass bottles in triplicates. The samples were stored at $4^{\circ} \mathrm{C}$ until analysis, which was done within $24 \mathrm{~h}$ of the sample collection. To isolate E. coli, serial dilutions of the sample were prepared in $0.85 \%$ $\mathrm{NaCl}$, and were used to inoculate MacConkey agar and Eosin Methylene Blue medium agar. Plates were incubated overnight at $37^{\circ} \mathrm{C}$. For further identification, possible E. coli were confirmed by testing for glucuronidase activity (growth and fluorescence in EC-MUG), citrate utilization, indole production, methyl red test and Voghes-Proskauer test. Isolates meeting the E. coli test profile were confirmed by detecting the uidA gene using uidA primers listed in Table 2. The E. coli isolates were stored at $-80^{\circ} \mathrm{C}$ in tryptic soy broth and 20\% (vol/vol) glycerol.

\section{PHYSICOCHEMICAL PARAMETERS}

All techniques were performed according to Standard Methods (APHA, 1998). Water temperature (Method 2550B), pH (Method $4500-\mathrm{H}+\mathrm{B})$, conductivity (2510B) and dissolved oxygen (4500 OG) were determined electrometrically in situ. The level of organic matter pollution was determined using the biological oxygen demand (BOD, 5210B) and chemical oxygen demand (COD, 5220D). Total nitrogen (4500-NorgB), total phosphorus (4500-PE) and total suspended solids (TSS) (2540B-F) were also determined. 


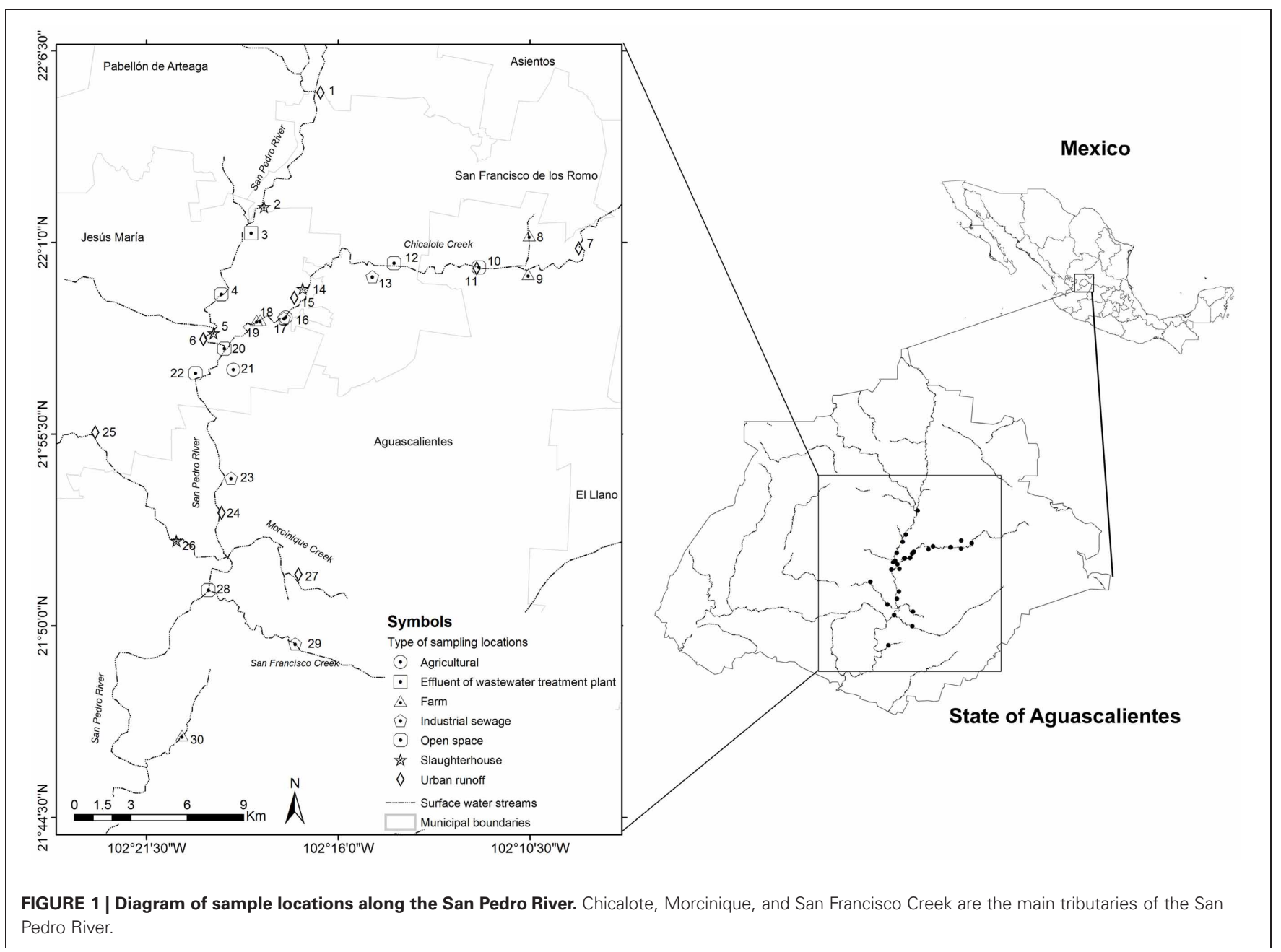

\section{MICROBIOLOGICAL ANALYSIS}

The amount of total bacteria was estimated by testing for mesophilic microorganisms using the pour plates technique (9215B). Fecal contamination was determined by measuring total coliform (9221C) and fecal coliform (9221E) using the standard fermentation technique for the most probable number (MPN; APHA, 1998).

\section{ANTIMICROBIAL SUSCEPTIBILITY TESTING}

Antimicrobial susceptibility test of 150 E. coli isolated from stream water was performed using a disc diffusion assay according to CLSI standards, 2010. Isolates that were resistant to three or more antimicrobial agents were defined to have a multiple drug resistant (MDR) phenotype. E. coli ATCC 25922 (American Type Culture Collection, Manassas, VA, US), was included in each assay as a negative control. Antimicrobial agents were tested using a Bio-Rad (Hercules, CA, US) Sensi-Disc antimicrobial susceptibility test multidisc for Gram-negative bacteria with the following antimicrobial agents: amikacin-30, ampicillin-10, cephalothine-30, cephotaxim-30, ceftriaxone-30, chloramphenicol-30, gentamicin-10, netilmicin30, nitrofurantoin-300, pefloxacin-5, carbenicillin-30, and trimethoprim-sulfamethoxazole-1.25/23.75 $\mu \mathrm{g}$. The quinolone levofloxacin-5 $\mu \mathrm{g}$ was tested separately using a Bio-Rad (Mexico, DF, Mexico) Sensi-Disc.

\section{DNA EXTRACTION}

E. coli isolates were grown overnight in $5 \mathrm{~mL}$ of Luria-Bertani broth at $37^{\circ} \mathrm{C}$ without shaking. An aliquot $(1 \mathrm{~mL})$ of the overnight culture was transferred to $1.5 \mathrm{~mL}$ tubes and centrifuged at $15,500 \times g$ for $2 \mathrm{~min}$. The supernatant was removed, and the cell pellet was resuspended by vortexing in $200 \mu \mathrm{L}$ of sterile water. The suspension was boiled for $15 \mathrm{~min}$, centrifuged $(15,500 \times g$, $2 \mathrm{~min}$ ), and $150 \mu \mathrm{L}$ of the supernatant was collected (Hamelin et al., 2006). The DNA quality and purity extracted was analyzed by spectrophotometer at 260 and $280 \mathrm{~nm}$ wavelengths. The sample with ratio $\left(\lambda_{260} / \lambda_{280}\right) \geq 1.5$ was considered adequate to continue with identification by polymerase chain reaction (PCR).

\section{PATHOTYPE AND VIRULENCE GENES DETERMINATION BY PCR}

Detection of intestinal pathogenic E. coli (InPEC) and ExPEC virulence genes were performed by PCR with primers described in Table 2. InPEC isolates were defined according to criteria established by Aranda et al., 2007 and ExPEC isolates were defined by 
Table 1 | Location and main sources of pollution of the 30 sampling locations studied.

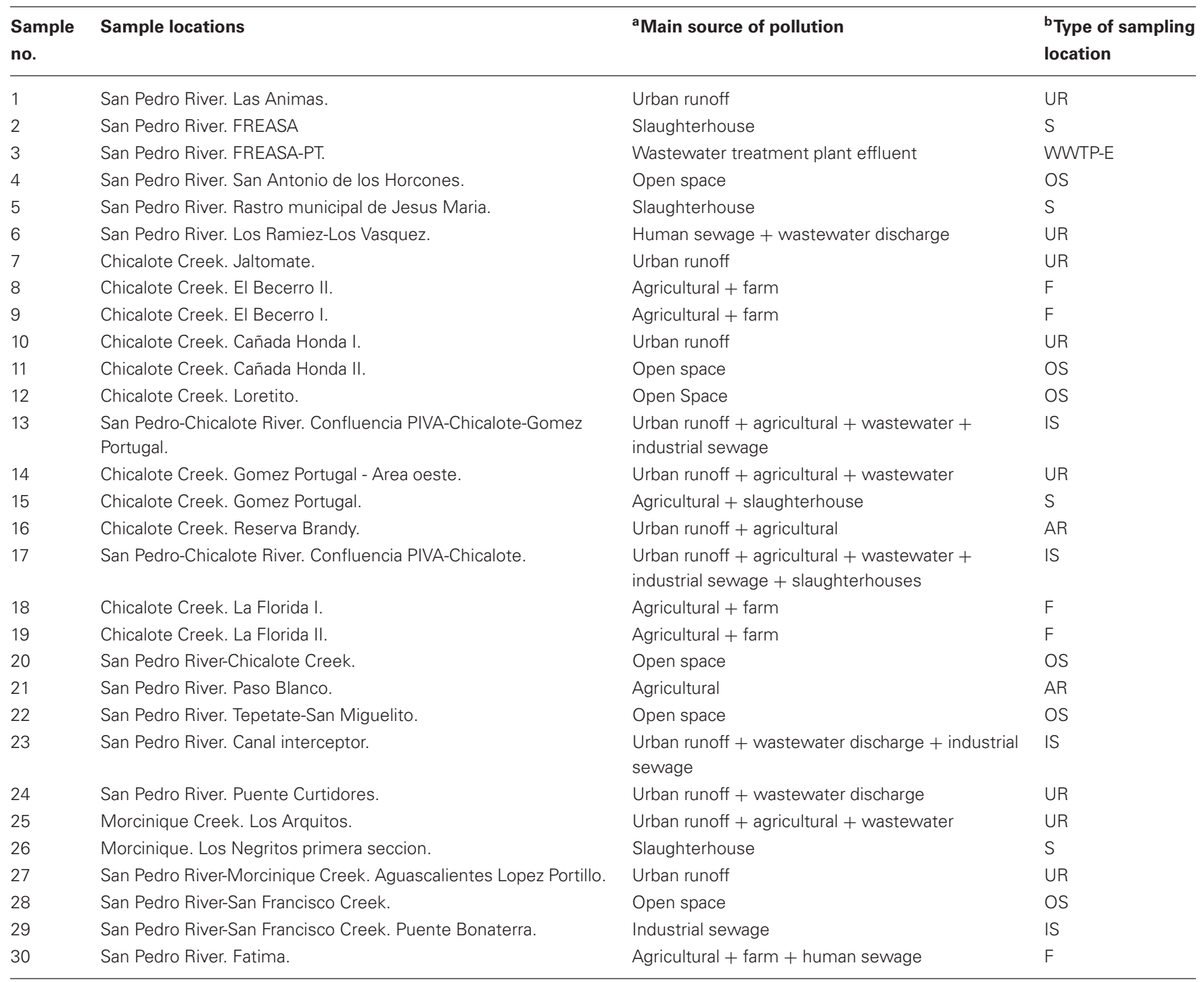

${ }^{a}$ Main source of pollution of location was determined based on the presence of discharge nearby and the type of land activity.

${ }^{b} A R$, agriculturally impaired; F, farm; IS, industrial sewage; OS, open spaces; S, slaughterhouse; UR, urban runoff; WWTP-E, wastewater treatment plant effluent.

criteria described by Johnson and Stell, 2000. Positive controls are listed in Table 3.

\section{CHROMOSOMAL-ENCODED AND ACQUIRED OUINOLONE RESISTANCE GENES}

Eighteen quinolone resistant and intermediate resistant isolates were selected to investigate mutations in the QRDR of gyrA and $\operatorname{par} C$ genes, as well as the presence of the acquired genes $q n r A$, qnrB, qnrS, and $a a c\left(6^{\prime}\right)-I b c r$. The oligonucleotides and PCR conditions used in this study are listed in Table 2. The quinolone resistance determining regions of $\operatorname{gyr} A$ and $\operatorname{par} C$ genes were amplified and sequenced as described by Namboodiri et al. (2011). Amplicons were sequenced on both strands and predicted peptide sequences were compared to the corresponding gene from the MG1655 genome using BLAST program in Geneious R6 software (v. 6.0., Biomatters Ltd., New Zealand). The strains
J53pMG252, J53pMG298, and J53pMG306 were used as positive controls for $q n r A$, $q n r B$, and $q n r S$, respectively (Jacoby et al., 2003) and water was used as negative control. The aac (6')-Ib cr genes was detected as described by Park et al. (2006) with some modifications. Primers were used as follows: aac-forward (5'-TTGCGATGCTCTATGAGTGGCTA-3') and aac-reverse (5'CTCGAATGCCTGCGCTGTTT- $3^{\prime}$ ) to yield an amplicon of 482 bp. The PCR condition were $94^{\circ} \mathrm{C}$ for $4 \mathrm{~min}, 35$ cycles of $94^{\circ} \mathrm{C}$ of $30 \mathrm{~s}, 58^{\circ} \mathrm{C}$ for $30 \mathrm{~s}$, and $68^{\circ} \mathrm{C}$ for $45 \mathrm{~s}$, and a final step of $68^{\circ} \mathrm{C}$ for $10 \mathrm{~min}$. Positive controls are listed in Table 3. The aac (6 $\left.6^{\prime}\right)-\mathrm{Ib}$ cr variant was identified by sequencing the PCR products (Park et al., 2006).

\section{DNA MICROARRAY ANALYSIS}

Microarray hybridizations were performed using E. coli Maxivirulence version 3.1 microarray as previously described 
Table 2 | Oligonucleotides used in this study.

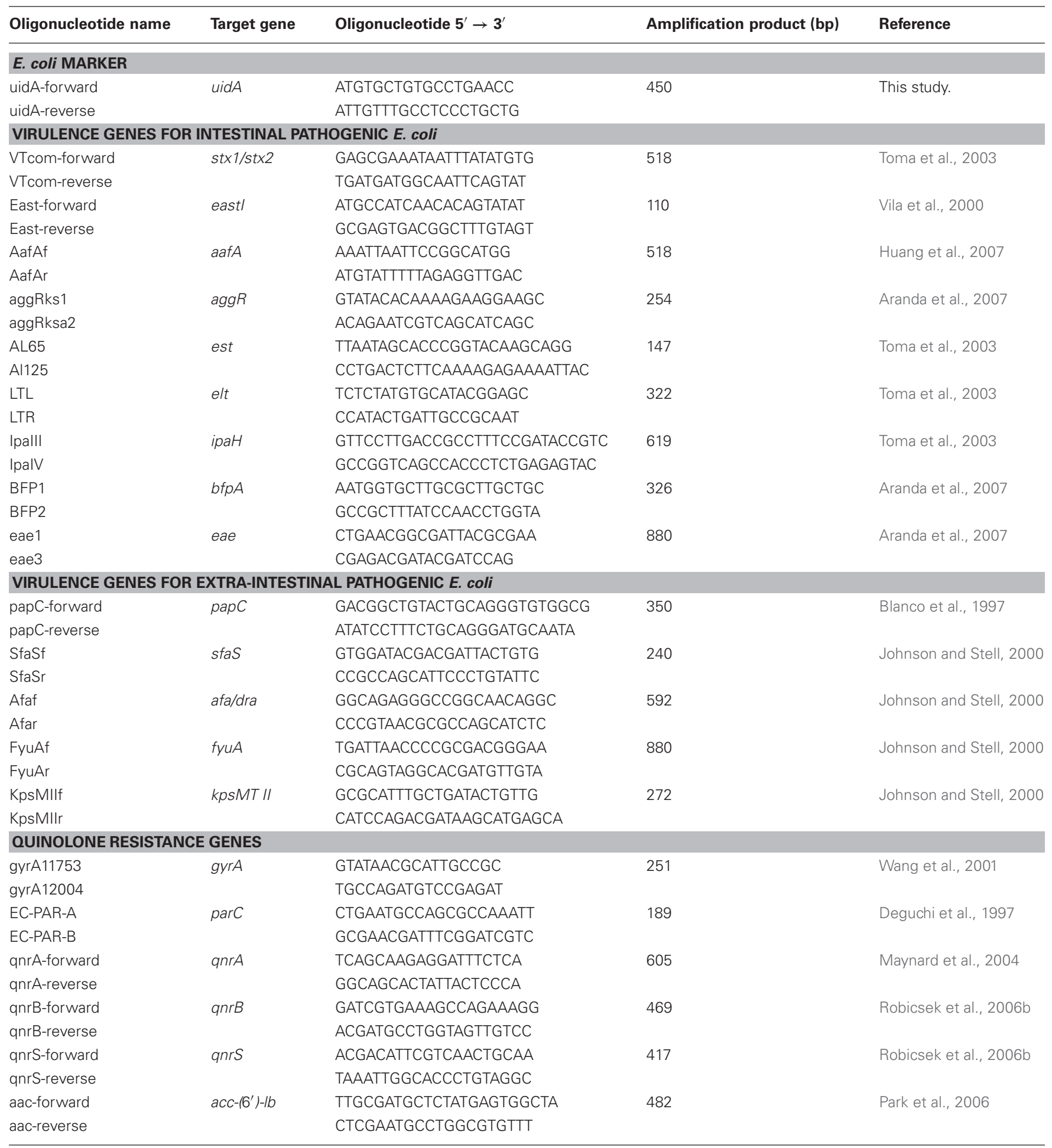

(Jakobsen et al., 2011). It allows the detection of 348 virulence genes and 98 antibiotic resistance genes and variants. DNA extraction and hybridizations were performed as described previously (Bruant et al., 2006). Each isolate was assigned to a specific E. coli pathotype according to its virulence gene profile and based on classification described previously (Bonnet et al., 2009; Jakobsen et al., 2011). E. coli isolates were also assigned to a phylogenetic group based on the presence of chuA, TspE4.C2, and yjaA as described previously (Clermont et al., 2000). 
Table 3 | PCR control strains used in this study.

\begin{tabular}{ll}
\hline Strain & Positive gene (s) \\
\hline ETEC H10407 & elt and est \\
EHEC EDL933 & sxt1 and sxt2 \\
EPEC 2349/69 & eae and bfpA \\
EAEC O42 & aggR and aaf genes \\
Shigella flexneri & ipaH \\
J53pMG252 & qnrA \\
J53pMG298 & qnrB \\
J53pMG306 & qnrS \\
Salmonella SA20042859 & aac(6')-lb \\
\hline
\end{tabular}

\section{STATISTICAL ANALYSIS}

Comparisons of associations between resistant phenotypes in E. coli isolated from stream were performed separately by using Pearson's chi-square exact test and Fisher's exact test (STATISTICA V. 10, StatSoft, US). Spearman's rank correlation (West et al., 2011) was used to examine the relationships among temperature, $\mathrm{pH}$, conductivity, dissolved oxygen, COD, BOD, total phosphorus, nitrogen, total solid suspended, mesophilic bacteria and total and fecal coliform density across all sample locations.

\section{RESULTS}

\section{PHYSICOCHEMICAL ANALYSES OF SAN PEDRO RIVER}

The physicochemical properties of each sample locations of the San Pedro River (Figure 1) were characterized using parameters such as temperature, DO, pH, BOD, and COD. These parameters were included because they have a major influence on bacterial growth (Salem et al., 2011). Results of physicochemical parameters are shown in the Figure 2. The mean value for water temperature was $24.2^{\circ} \mathrm{C}$, which is usually considered a favorable temperature for the growth of microorganisms as well as for a wide range of human and animal pathogens. The $\mathrm{pH}$ values of water samples varied between 6.7 and 8.2 units, with a mean value of 7.6 units. The $\mathrm{pH}$ values were within the permissible limits (6.0-9.0) established by the WHO for wastewater discharge into the sea or the environment. Furthermore, this $\mathrm{pH}$ range value is optimal for bacterial growth.

The dissolved oxygen concentrations (DO) for almost all the sample locations were lower than $1 \mathrm{mg} / \mathrm{L}$ suggesting high organic matter levels. These DO concentrations are near anoxygenic conditions, which allow the growth of a broad spectrum of both aerobic and anaerobic microorganisms. For conductivity, $96.6 \%$ of the samples were above the WHO guideline value of $1000 \mu \mathrm{S} / \mathrm{cm}$ for wastewater discharging into a stream. These conductivity levels imply high concentrations of dissolved inorganic matter suggesting that high concentrations of inorganic nutrients are available for microbial proliferation. Significant differences in conductivity were observed between location sites close to farms and slaughterhouses $(p<0.001)$ compared to other types of sample locations.

The indicators of organic matter, COD and BOD, were generally high along sample locations (Figure 2). This confirms the discharge of raw wastewater of urban runoff including municipal origin into the river. The mean values were 722 and $1723 \mathrm{mg} / \mathrm{L}$ for BOD and COD, respectively, representing a high organic load in the river. Sample locations with highest levels of BOD and COD were related to farms, urban runoff, industrial sewage and slaughterhouses. All water samples were above the maximum permissible limit of organic matter (BOD $<200 \mathrm{mg} / \mathrm{L}$ ) set by Mexican Norms (NOM-001-ECOL-1996) for streams discharged into rivers used for agricultural irrigation. These results showed abundant carbon and energy sources to support the heterotrophic growth of microorganisms.

Total solid suspended (TSS) were correlated with concentration of COD, BOD, and mesophilic bacteria [TSS-COD, $r_{s}=$ $0.79, p=0.05$; TSS-BOD, $r_{s}=0.79, p=0.05$; TSS-mesophilic bacteria density, $\left.\left.r_{s}=0.89, p=0.012\right)\right]$. The measured concentrations of COD and BOD showed a strong correlation $\left(r_{s}=1\right.$, $p>0.001)$. All the sample locations exceed the total phosphorus threshold of $0.1 \mathrm{mg} / \mathrm{L}$ as well as the nitrogen threshold $(1 \mathrm{mg} / \mathrm{L})$. Temperature and nitrogen concentration were negatively correlated $\left(r_{s}=-0.79, p=0.048\right)$. Total phosphorus concentration was strongly negatively correlated with dissolved oxygen concentration $\left(r_{s}=-0.96, p=0.003\right)$. Literature classifies wastewater TSS as follows: TSS less than $100 \mathrm{mg} / \mathrm{L}$ as weak, TSS greater than $100 \mathrm{mg} / \mathrm{L}$ but less than $220 \mathrm{mg} / \mathrm{L}$ as medium and TSS greater than $220 \mathrm{mg} / \mathrm{L}$ as strong wastewater. Results of this study classified the sample locations located near to wastewater treatment plant effluent as weakly contaminated wastewater, which reflects the efficiency of wastewater treatment. Less contaminated sample locations close to open space were classified as medium wastewater. In total, 27 sample locations were classified as polluted sites and only three as less polluted. Locations number three (wastewater treatment plant effluent), 15 (slaughterhouse) and 25 (urban runoff) were categorized as less polluted sites in base of their physico-chemical results (Figure 1).

\section{BACTERIOLOGICAL ANALYSIS}

The mesophilic microorganism counts were between $10^{4}$ and $10^{6} \mathrm{CFU}$ and these measurements were consistent with the high levels of organic and inorganic nutrients found in the San Pedro River, and the favorable physicochemical conditions for microbial growth found in the river (Figure 3). Although agricultural, farm and industrial sewage site locations tended to have greater counts of mesophilic bacteria than open space, no significative differences were found $(p>0.05)$. Half of the samples exceeded the limit of $1000 \mathrm{MPN} / 100 \mathrm{~mL}$ (WHO, 2006). Some samples were as low as $1 \mathrm{MPN}$ and others as high as $2.4 \times 10^{4} \mathrm{MNP} / 100 \mathrm{~mL}$. Some samples presented low fecal coliforms counts as low as $0.5 \mathrm{MPN}$ and others were as high as $1 \times 10^{4} \mathrm{MNP} / 100 \mathrm{~mL}$. Statistically significant associations were found between the levels of total and fecal coliforms and water temperature $(p=0.02)$, and between coliforms and conductivity $(p=0.03)$, suggesting fecal bacteria proliferation due to appropriate conditions in the water environment. Total and fecal coliform were strongly correlated $\left(r_{s}=0.86, p=0.023\right)$. Industrial sewage and urban runoff sites tended to have greater total and fecal coliform densities than the agricultural, farm locations and wastewater treatment plant effluent. 

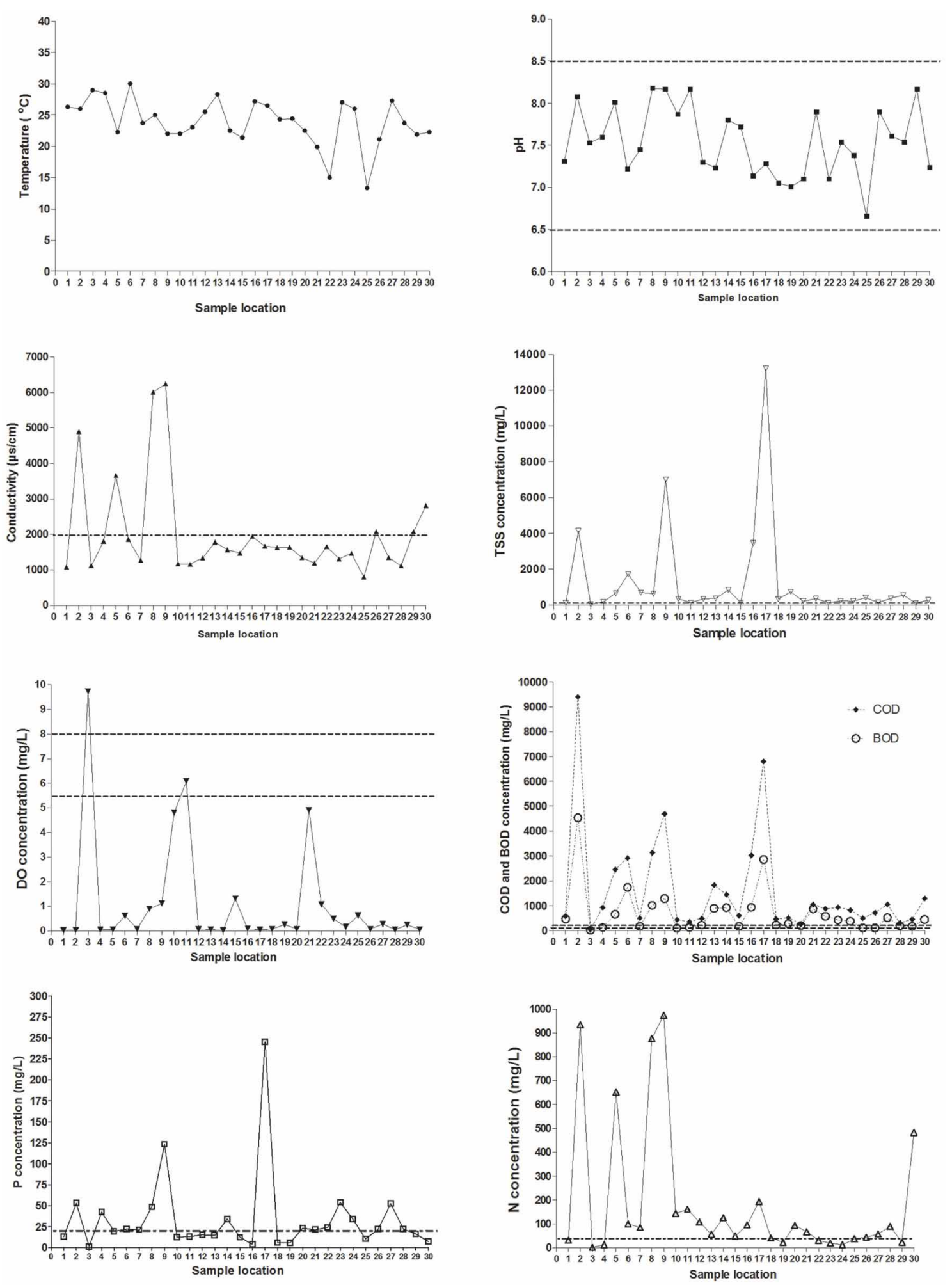

FIGURE 2 | Spatial variation of physico-chemical parameters from sampling locations on the San Pedro River. Permissible maximum limits are shown in dotted lines. $\mathrm{pH}$ values between 6.5 and 8.5 units are considered as good quality in potable water (NOM-127-SSA1-1994). Conductivity values above $2000 \mu \mathrm{S} / \mathrm{cm}$ are exceeding the permissible limits. Nitrogen values above $40 \mathrm{mg} / \mathrm{L}$ are exceeding the permissible limits.

Phosphorus levels rating higher than $20 \mathrm{mg} / \mathrm{L}$ is considered as poor water quality. Total solid suspended has a permissible value of $120 \mathrm{mg} / \mathrm{L}$. Dissolved oxygen concentration limits are between 5.5 and $8.0 \mathrm{mg} / \mathrm{L}$ (Gúzman-Colis et al., 2011). BOD and COD concentrations limits are 150 and $100 \mathrm{mg} / \mathrm{L}$ respectively according to Mexican norms NOM-003-ECOL-1997 and NOM-001-ECOL-1996. 


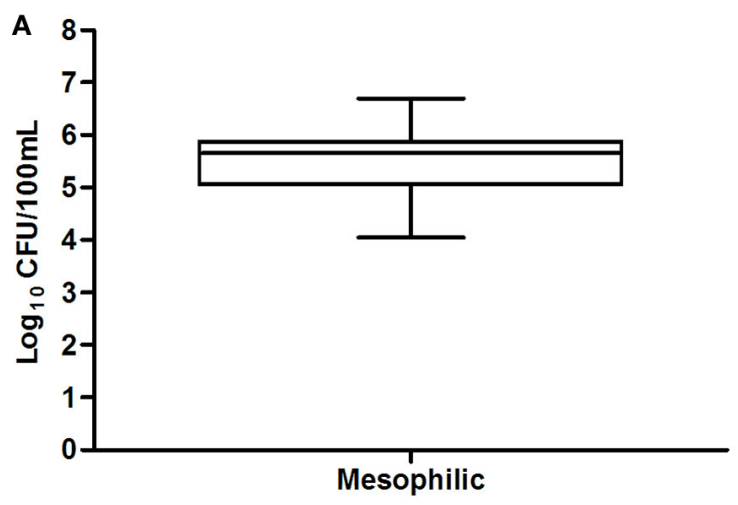

FIGURE 3 | Box and whiskers plot of results of microbiological analyses of San Pedro River in thirty sample location. Bacterial counts values are shown in a $\log _{10}$ scale, (A) mesophilic microorganisms (B) total and fecal coliforms. Permissible maximum

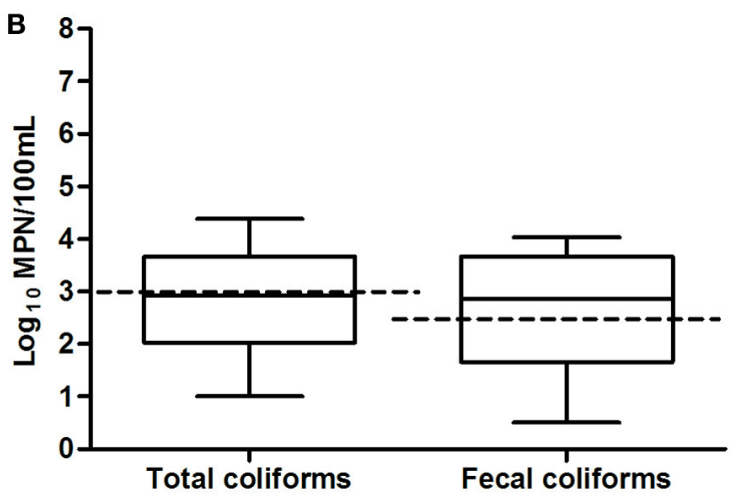

limits are shown in dotted lines. Total and fecal coliform density rating above $1000 \mathrm{MPN} / 100 \mathrm{~mL}$ and $240 \mathrm{MPN} / 100 \mathrm{~mL}$ are considered as poor water quality according to Mexican norms NOM-003-ECOL-1997 and NOM-001-ECOL-1996.

\section{ANTIBIOTIC RESISTANCE PHENOTYPES OF E. coli ISOLATES}

The antimicrobial susceptibility of $150 \mathrm{E}$. coli isolated from the San Pedro River to 13 antimicrobial agents was measured by the disc diffusion method (CLSI, 2010). Fifty-two percent (79/150) of the isolates were resistant to at least one antimicrobial agent; $37.3 \%(56 / 150)$ were resistant to at least two and $30.6 \%(46 / 150)$ were multi-drug-resistant. A total of 59 isolates $(39.3 \%)$ were resistant to ampicillin (Figure 4). The second most prevalent antibiotic resistance was toward trimethoprimsulfamethoxazole (28.6\%, 43/150 isolates), followed by carbenicillin $(26 \%, 39 / 150$ isolates), chloramphenicol (22\%, 33/150 isolates), and cephalothine (17.3\%, 26/150 isolates). Few isolates $(1.33 \% ; 2 / 150)$ had a resistance toward cephotaxim, netilmicin and amikacin. Interestingly, it was noticed that $7.3 \%(11 / 150)$ of the isolates were resistant to pefloxacin and 4\% (6/150 isolates) were resistant to levofloxacin (Figure 4). These antibiotics are second and third-generation quinolones widely used in Mexico against intestinal and UTIs (Guajardo-Lara et al., 2009). Furthermore, 12 strains were FQ-resistant and presented a multiresistant phenotype. Most E. coli isolates with resistance to FQ were found in the sample locations close to farms, agricultural areas, urban runoff and industrial sewage.

Among isolates with a multi-resistant phenotype, $1.3 \%$ (2/150) was resistant to seven antimicrobial agents; $3.3 \%(5 / 150)$ were resistant to six antimicrobial agents; 5.3\% (8/150) were resistant to five antimicrobial agents, $7.3 \%(11 / 150)$ were resistant to four antimicrobial agents and 13\% (20/150) were resistant to three antimicrobial agents. The location sites close to discharges from urban runoff and industrial sewage had a more important proportion of isolates that were resistant to multiple antibiotics (15 isolates and 10 isolates respectively, Figure 5). Wastewater treatment plant effluent and agricultural locations had the lowest proportion of antibiotic resistant bacteria with only two multiresistant and one resistant bacteria in each location. Urban runoff locations as well as industrial sewage, open space and slaughterhouse sample locations had the most important counts of antibiotic resistant bacteria. Urban runoff sample

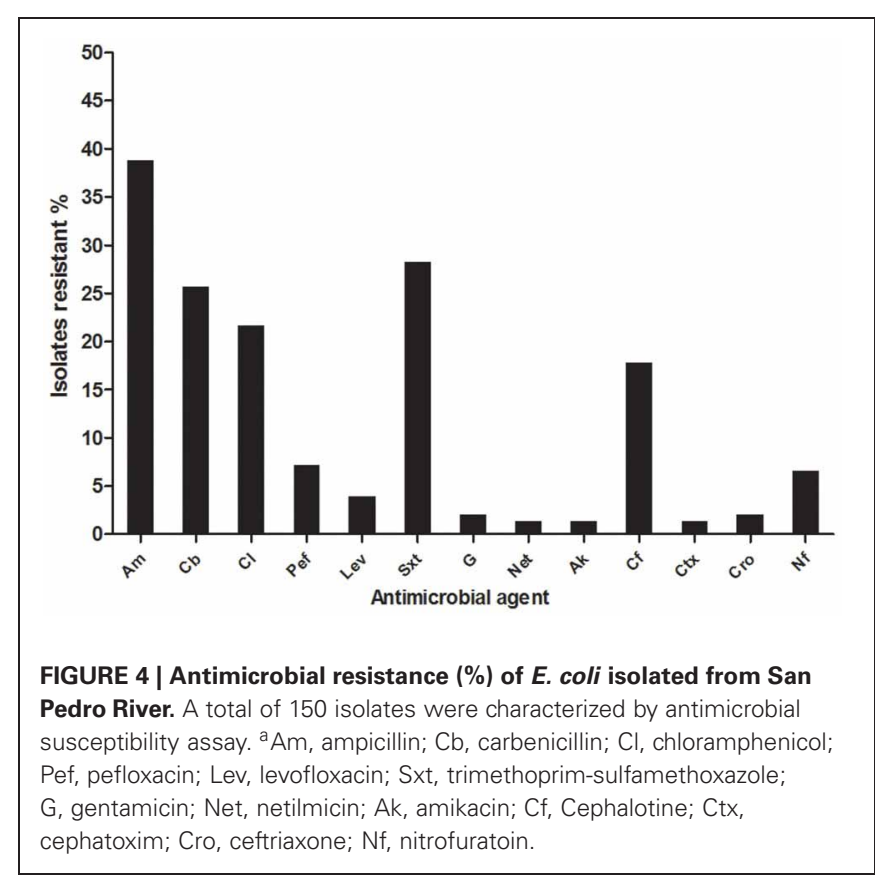

locations were also the locations with highest density of total and fecal coliforms. Additionally, even when farm locations presented low proportion of antibiotic resistant bacteria, these locations presented multidrug resistance patters to more antibiotic classes (Figure A1). Non-resistant bacteria were found in samples isolates from farms (site locations No. 8 and 30), urban runoff (site location No. 14) and agricultural (site location No. 21) locations (Figure 5). Furthermore, density of multiresistant bacteria was negatively-correlated with nitrogen concentration $\left(r_{s}=-0.78\right.$, $p=0.04)$.

A noticeable result shows that a co-resistance to beta-lactams and sulfonamides was frequently observed because most of sulfonamide-resistant isolates were also resistant to beta-lactams (Table 5). Resistance phenotype to quinolones was associated 


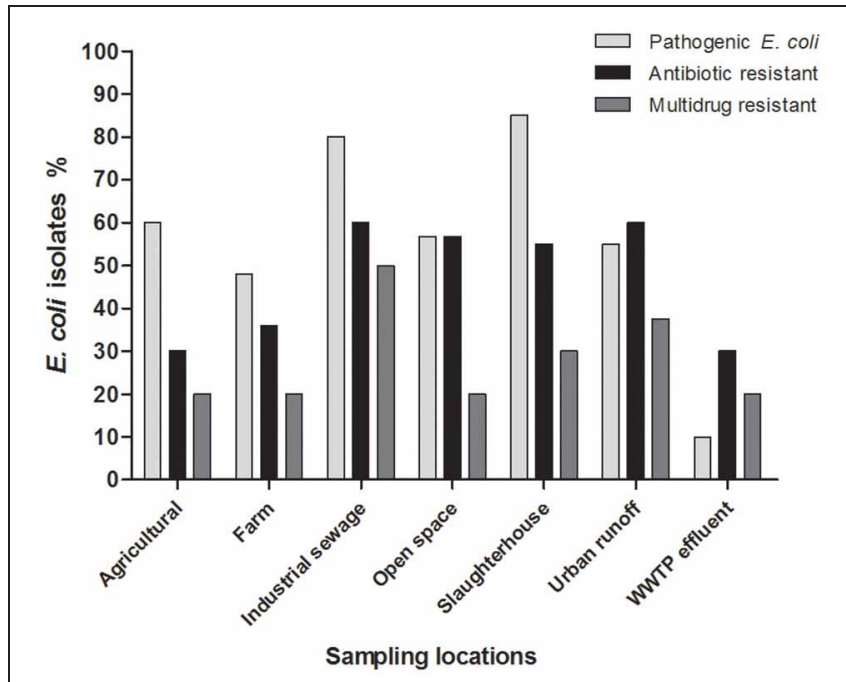

FIGURE 5 | Antimicrobial resistant, multidrug resistant, and potentially pathogenic Escherichia coli isolates found according to the sample location. aWWTP-E, wastewater treatment plant effluent.

with beta-lactams and sulfonamides resistance $(0.05 \geq p \geq$ $0.01)$, and beta-lactams and phenicols resistance $(0.01 \geq p \geq$ $0.001)$.

Wastewater treatment plant effluent sample, which was considered as less polluted based on tested parameters (Figures 2, 3) presented proportion of antibiotic resistant bacteria similar to that of the agricultural sector $(30 \%)$. Nevertheless, samples from industrial sewage had the highest proportion of multidrug resistant bacteria (50\%) suggesting that industrial sewage might have an impact on the presence of multidrug resistant bacteria.

\section{PATHOTYPE AND VIRULENCE GENES DETERMINATION OF E. coli ISOLATES}

Sixty percent $(91 / 150)$ of the strains were PCR positive for at least one virulence gene (Aranda et al., 2007). Eighty-six isolates were identified as InPEC, including 44.6\% (67/150) EAEC, 6.6\% (10/150) EPEC, and 6\% (9/150) ETEC (Table 4). Only 5 (3.3\%) isolates were identified as incomplete ExPEC because these isolates were positive for the virulence genes fyuA, kpsMII, sfa, and afa/dra (Johnson and Stell, 2000). EIEC and Shiga-toxigenic E. coli were not detected. In addition, slaughterhouse (85\%, 17/20 isolates), industrial sewage ( $80 \%, 16 / 22$ isolates) and agricultural (60\%, 6/10 isolates) sample locations had the most important proportion of pathogenic bacteria.

Furthermore, strains belonging to the pathotypes EPEC ( $n=$ $7)$, ETEC $(n=4)$, EAEC $(n=37)$ and incomplete ExPEC $(n=4)$ were at least resistant to one antimicrobial agent. Among strains with a multi-antimicrobial resistance phenotype, 22 were EAEC, 4 were ETEC isolates, 6 were EPEC, and 1 was an incomplete ExPEC. Most pathogenic E. coli that had multi-resistant phenotype were resistant to beta-lactams and trimethoprim-sulfamethoxazole. Amongst the commensal E. coli, multi-resistance was also detected in 22\% (13/59) of the isolates.
Significative differences between number of pathogenic isolates $(p=0.02)$ and isolates with resistance to one antimicrobial agent $(p=0.04)$ were found when comparing polluted samples with that of less polluted sample sites. Non-statistical differences were found compared multidrug resistance $(p>0.05)$. This suggests that in polluted water there are more pathogenic bacteria (Figure 5).

CHARACTERIZATION OF OUINOLONE RESISTANCE IN E. coli ISOLATES

The genotypes associated with the quinolone resistance (including intermediate resistance) phenotype were characterized for seven pathogenic E. coli and 11 commensal E. coli. Three of 18 isolates were resistant to second generation quinolones (levofloxacin and pefloxacin), nine isolates were resistant to one of the two quinolones and six showed intermediate resistance to pefloxacin (6/18 isolates). Resistance to quinolones was usually observed in strains with a multi-drug resistance phenotype $(16 / 18$ isolates).

The sequencing results for the QRDR of gyrA and parC are summarized in Table 6. The Ser-83 $\rightarrow$ Leu and Asp-87 $\rightarrow$ Asn substitution in gyrA and the Ser- $80 \rightarrow$ Ile substitution in $\operatorname{par} C$ were found in isolates resistant to both levofloxacin and pefloxacin $(n=2)$, to levofloxacin alone $(n=2)$, and to pefloxacin alone $(n=3)$. E. coli isolates with only the Ser-83 $\rightarrow$ Leu and Asp-87 $\rightarrow$ Asn substitution in gyrA showed resistance and intermediate resistance to pefloxacin. A single mutation in gyrA at Ser-83 $\rightarrow$ Leu $(n=2)$ was found in one strain resistant to both (levofloxacin and pefloxacin), and one with intermediate resistance to pefloxacin. An isolates with a single mutation (Ser$80 \rightarrow$ Ile) in parC exhibited an intermediate resistance toward pefloxacine. Three strains had one or more qnr genes. Five E. coli isolates possessed $q n r A$, seven isolates had $q n r S$ and two isolates had $q n r B$. Overall, eight isolates had chromosomal mutations in gyrA, parC or both as well as horizontally acquired $q n r$ genes. The $q n r$ genes were found in two strains with a triple mutation profile $($ Ser-83 $\rightarrow$ Leu, Asp-87 $\rightarrow$ Asn in gyrA and Ser-80 $\rightarrow$ Ile in parC) that were resistant to both levofloxacin and pefloxacin. Quinolone resistance isolates $(n=3)$ with one mutation Ser-83 $\rightarrow$ Leu in gyr $A$, or, Ser- $80 \rightarrow$ Ile in parC possessed also $q n r$ genes. The three strains with no chromosomal mutation possessed one or two $q n r$ genes. One of the isolates did not have either a chromosomal mutations or $q n r$ genes. In addition, the ETEC pathotype isolate 18A (Table 6) exhibited a multi-resistance phenotype and had three substitutions (Ser-83 $\rightarrow$ Leu, Asp-87 $\rightarrow$ Asn in gyrA and Ser- $80 \rightarrow$ Ile in parC), qnrS and the newly described aac (6')$\mathrm{Ib}$ - $\mathrm{cr}$ gene. Additionally, five isolates that had the triple mutation profile (Ser-83 $\rightarrow$ Leu, Asp-87 $\rightarrow$ Asn in gyrA and Ser-80 $\rightarrow$ Ile in $p a r C$ ) in the QRDR carried also one $q n r$ gene ( $q n r A$ or $q n r S$ ) and at least one beta-lactamase gene.

\section{VIRULENCE AND ANTIMICROBIAL RESISTANCE GENES AMONG OUINOLONE RESISTANT E. coli ISOLATES}

Microarray analysis was done on 17 quinolone resistant E. coli isolates. Based on the microarray analysis, nine isolates were classified as commensal and six were classified as InPEC, ExPEC, or potentially pathogenic E. coli. The isolates belonged to the phylotype group A (14 isolates), group D (1 isolate) and B1 (2 isolate). 
Table 4 | Antimicrobial resistance found in potentially pathogenic and commensal Escherichia coli.

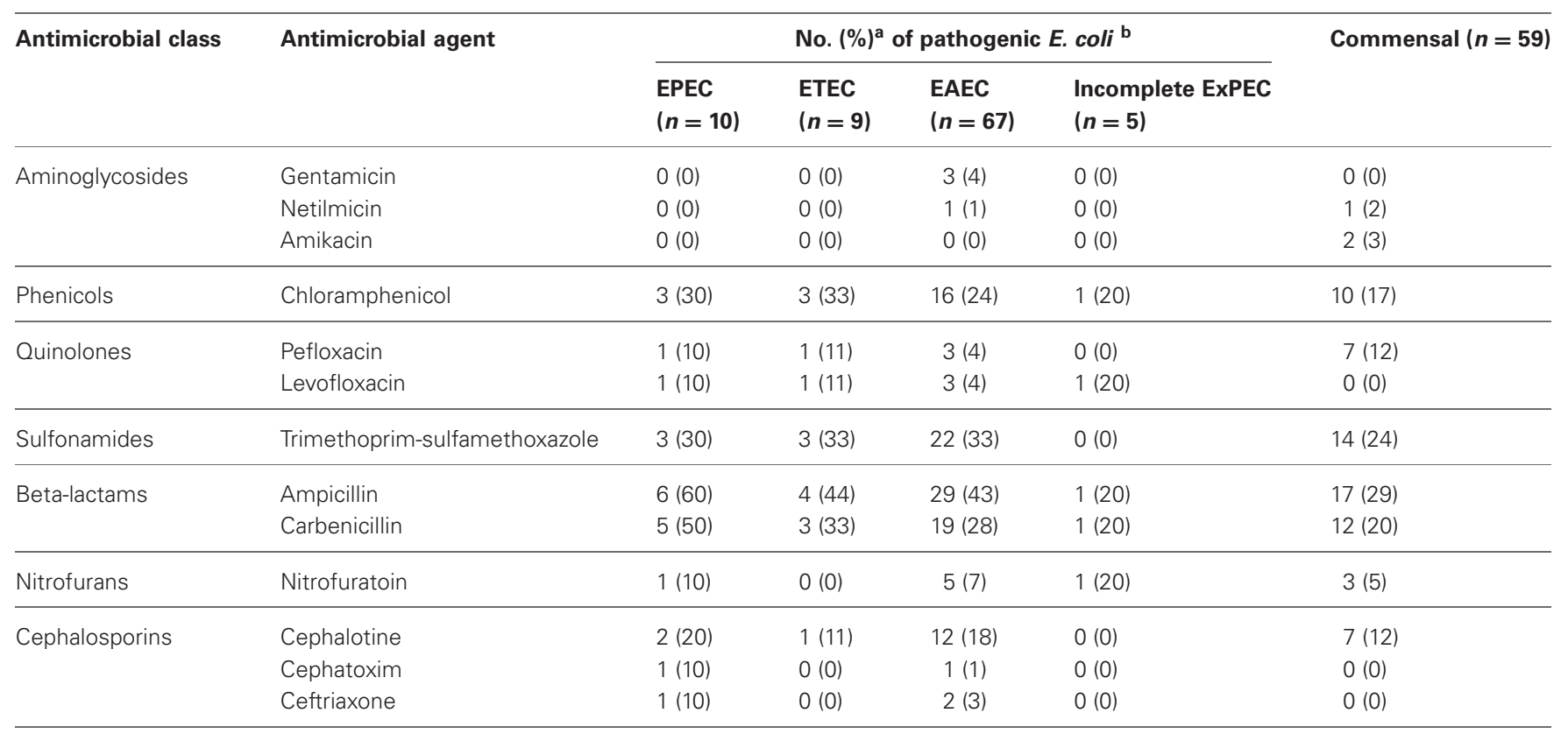

a Percentages were calculated as follows: number of isolates with resistance phenotype/total number of E. coli isolates per pathotype per 100.

${ }^{b} E P E C$, enteropathogenic E. coli. ETEC, enterotoxigenic E. coli. EAEC, enteroaggregative E. coli. Incomplete ExPEC, incomplete extra-intestinal pathogen E. coli.

Table 5 | Association between antimicrobial resistance phenotypes of $E$. coli isolates from stream water.

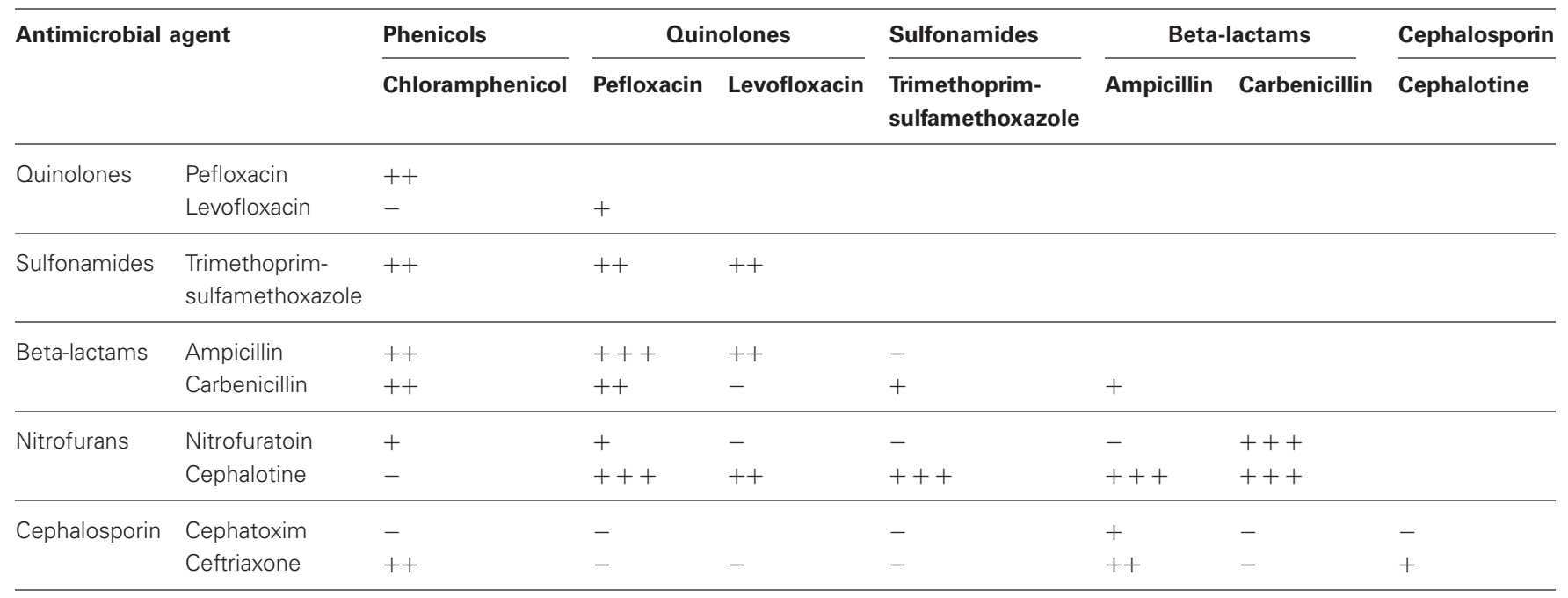

Only the antimicrobial multi-resistant phenotypes that exhibited an association with another phenotype at the $p<0.05$ level are shown. The levels of significance of the association as assessed by the chi-square exact test were as follows:,$- p>0.05 ;+, 0.05 \geq p \geq 0.01 ;++, 0.01 \geq p \geq 0.001 ;+++, 0.001 \geq p$.

The most frequent antimicrobial resistance genes were aph3strA (10/17), bla TEM $_{\text {(10/17) and } \operatorname{tet}(B)}$ (5/17), which code for resistance to streptomycin, ampicillin, and tetracycline respectively (Table 6). Class 1 integron markers were also found in ten isolates. A bla TEM and aph3(strA) combination was observed in nine isolates, and a bla $a_{\mathrm{TEM}}, a p h 3(\operatorname{str} A)$ and $\operatorname{tet}(B)$ combination was observed in six isolates. In our study, 10 quinolone resistance isolates also carried $b l a_{\text {TEM }}$ gene. Among these 10 isolates, nine isolates were positive for the beta-lactamase gene and a plasmid acquired resistance gene.
Isolates with $q n r$ genes and the triple mutation patter in the QRDR were found in sample locations close to farm and agricultural sector (Figure 1, Table 6). Nevertheless, isolates with intermediate-resistance to FQ phenotypes were found in sample locations close to urban runoff, industrial sewage, slaughterhouses, open space and wastewater treatment plant. Interestingly, samples with resistance to one or other FQ phenotype were sampled in locations close to urban runoff, industrial sewage, open space, farm, and agricultural sectors (Table 6, Figures 1, 5). 
Table 6 | Summary of the pathotype, antimicrobial resistance patterns, QRDR mutation and presence of qnr resistance genes for the 18 . coli isolates selected for their resistance to fluoroquinolones of second (pefloxacin) and third (levofloxacin) generation.

\begin{tabular}{|c|c|c|c|c|c|c|c|c|}
\hline \multirow[t]{2}{*}{ Strains ID } & \multirow[t]{2}{*}{ MDR phenotype ${ }^{a}$} & \multicolumn{2}{|c|}{ Diffusion disc $^{b}$} & \multicolumn{2}{|c|}{ QRDR mutation } & \multirow{2}{*}{$\begin{array}{l}\text { PMQR } \\
\text { genes }\end{array}$} & \multirow[t]{2}{*}{ Other resistance genes } & \multirow[t]{2}{*}{ E. coli type ${ }^{c}$} \\
\hline & & LEV & PEF & $\rightarrow$ GyrA & $\rightarrow$ ParC & & & \\
\hline $16 C$ & AmCbCISxtLevPef & $\mathrm{R}$ & $\mathrm{R}$ & $\begin{array}{l}\mathrm{S} 83 \rightarrow \mathrm{L} \\
\mathrm{D} 87 \rightarrow \mathrm{N}\end{array}$ & $\mathrm{S} 80 \rightarrow \mathrm{I}$ & qnrA & $\begin{array}{l}\text { aph3(strA), blatem, class } 1 \\
\text { integron }\end{array}$ & Incomplete ExPEC \\
\hline $18 \mathrm{~A}$ & AmCfCtxCroLevPefStx & $\mathrm{R}$ & $\mathrm{R}$ & $\begin{array}{l}\mathrm{S} 83 \rightarrow \mathrm{L} \\
\mathrm{D} 87 \rightarrow \mathrm{N}\end{array}$ & $\mathrm{S} 80 \rightarrow \mathrm{I}$ & $\begin{array}{l}\text { aac- }\left(6^{\prime}\right)-1 b-c r \\
\text { anrs }\end{array}$ & $\begin{array}{l}\text { aph3(strA), aph6(strB), blateM, } \\
\text { tet(B), tet(M) }\end{array}$ & InPEC \\
\hline $18 \mathrm{C}$ & AmCfCtxCroLevPefStx & $\mathrm{R}$ & $\mathrm{R}$ & $\mathrm{S} 83 \rightarrow \mathrm{L}$ & None & $\begin{array}{l}\text { aac- }\left(6^{\prime}\right)-1 b-c r \\
\text { anrs }\end{array}$ & $\begin{array}{l}\text { aph3(strA), aph6(strB), blateM, } \\
\text { dhfrVII, tet(B) }\end{array}$ & InPEC \\
\hline 17A & AmGLevSxt & $\mathrm{R}$ & S & $\begin{array}{l}\mathrm{S} 83 \rightarrow \mathrm{L} \\
\mathrm{D} 87 \rightarrow \mathrm{N}\end{array}$ & $\mathrm{S} 80 \rightarrow \mathrm{I}$ & None & $\begin{array}{l}\text { blaтем, aаc(3)-Ila(аacC2), } \\
\text { aph3(strA), mphA, sulll, class } 1 \\
\text { and } 2 \text { integron }\end{array}$ & InPEC \\
\hline 17D & AmCbGLev & $\mathrm{R}$ & S & $\begin{array}{l}\mathrm{S} 83 \rightarrow \mathrm{L} \\
\mathrm{D} 87 \rightarrow \mathrm{N}\end{array}$ & $\mathrm{S} 80 \rightarrow 1$ & None & $\begin{array}{l}\text { aph3(strA), blaтем, } \\
\text { aаc(3)-Ila(aаcC2), mphA, sull, } \\
\text { sulll, tet(B), class } 1 \text { integron }\end{array}$ & InPEC \\
\hline $17 \mathrm{E}$ & AmCbLev & $\mathrm{R}$ & S & None & None & None & $\begin{array}{l}\text { aph3(strA), blaTEM, dhfrXII, sulll, } \\
\text { tet(A) }\end{array}$ & Incomplete ExPEC \\
\hline $24 \mathrm{~A}$ & AmCbClCfPefSxt & S & $\mathrm{R}$ & $\begin{array}{l}\mathrm{S} 83 \rightarrow \mathrm{L} \\
\mathrm{D} 87 \rightarrow \mathrm{N}\end{array}$ & $\mathrm{S} 80 \rightarrow 1$ & qnrA & $\begin{array}{l}\text { aph3(strA), blaтем, dhfrXII, mphA, } \\
\text { sullI, tet(B), class } 1 \text { integron }\end{array}$ & Commensal \\
\hline $16 D$ & AmCbCIPefSxt & S & $\mathrm{R}$ & $\begin{array}{l}\mathrm{S} 83 \rightarrow \mathrm{L} \\
\mathrm{D} 87 \rightarrow \mathrm{N}\end{array}$ & $\mathrm{S} 80 \rightarrow 1$ & qnrA & $\begin{array}{l}\text { aph3(strA), blapse, blateM, catl, } \\
\operatorname{dhfrXII,~mphA,~tet(A),~tet(B),~sull,~} \\
\text { sullI, class } 1 \text { and } 2 \text { integron }\end{array}$ & Commensal \\
\hline $24 C$ & AmCbCIPefSxt & S & $\mathrm{R}$ & $\begin{array}{l}\mathrm{S} 83 \rightarrow \mathrm{L} \\
\mathrm{D} 87 \rightarrow \mathrm{N}\end{array}$ & $\mathrm{S} 80 \rightarrow 1$ & None & cmIAl, dhfrXII, class 1 integron & Commensal \\
\hline $24 \mathrm{E}$ & AmCbCIPefSxt & S & $\mathrm{R}$ & $\begin{array}{l}\mathrm{S} 83 \rightarrow \mathrm{L} \\
\mathrm{D} 87 \rightarrow \mathrm{N}\end{array}$ & $\mathrm{S} 80 \rightarrow \mathrm{I}$ & None & dhfrXII, cm|Al. & Commensal \\
\hline $1 \mathrm{~A}$ & CfNfPef & S & $\mathrm{R}$ & $\begin{array}{l}\mathrm{S} 83 \rightarrow \mathrm{L}, \\
\mathrm{D} 87 \rightarrow \mathrm{N}\end{array}$ & None & qnrs & $\operatorname{aph} 3(\operatorname{str} A)$ & Commensal \\
\hline $22 \mathrm{E}$ & Pef & S & $\mathrm{R}$ & None & None & qnrs & ND & Commensal \\
\hline $3 A$ & AmClStxPef & S & 1 & None & None & qnrA & $\begin{array}{l}\text { aph3(strA), blapSE, dhfrVII, sulll, } \\
\text { tet(A), class } 2 \text { integron }\end{array}$ & InPEC \\
\hline $2 \mathrm{E}$ & AmCIStxPef & S & 1 & $\begin{array}{l}\mathrm{S} 83 \rightarrow \mathrm{L} \\
\mathrm{D} 87 \rightarrow \mathrm{N}\end{array}$ & None & None & Class 1 and 2 integron. & Commensal \\
\hline $29 A$ & AmCbNfSxtPef & S & I & None & $\mathrm{S} 80 \rightarrow \mathrm{I}$ & qnrA, qnrB & blapse, dhfrXII, class 1 integron & InPEC \\
\hline $20 \mathrm{~A}$ & AmPef & S & I & None & None & $q n r B, q n r S$ & aph3(strA), blaтEM & Commensal \\
\hline $29 \mathrm{E}$ & AmCfCbSxtPef & S & 1 & None & None & qnrs & $\begin{array}{l}\operatorname{aad} A(1), \text { blaTEM, dhfrl, sull, class } \\
\text { 1and } 2 \text { integron, transposon Tn21 }\end{array}$ & InPEC \\
\hline $25 \mathrm{~A}$ & AmCbPef & $\mathrm{S}$ & I & $\mathrm{S} 83 \rightarrow \mathrm{L}$ & None & $q n r B, q n r S$ & Transposon Tn21 & Commensal \\
\hline
\end{tabular}

a Multi-drug resistance (MDR) phenotype, Am, ampicillin; Cb, carbenicillin; Cl, chloramphenicol; Pef, pefloxacin; Lev, levofloxacin; Sxt, trimethoprim-sulfamethoxazole; G, gentamicin; Net, netilmicin; Ak, amikacin; Cf, Cephalotine; Ctx, cephatoxim; Cro, ceftriaxone; Nf, nitrofuratoin. ND, not determined.

${ }^{b} R$, resistant; I, intermediate resistance; $S$, susceptible.

${ }^{c}$ InPEC, intestinal E. coli; EXPEC, extraintestinal E. coli. 


\section{DISCUSSION}

Aquatic environments such as rivers and streams are considered ideal reservoirs for antibiotic resistance dissemination, since antimicrobials and antimicrobial resistant bacteria are often directly released in the environment (Roe et al., 2003; Zhang et al., 2009b; Lupo et al., 2012). In developing countries, the contribution of sewage and wastewater as point sources, as well as animal farming without adequate outlet control, represent extra loads of contamination for aquatic systems. Most of the water from these activities is subsequently used for irrigation, without any treatment. This can represent potential risks of contamination (Mazari-Hiriart et al., 2008; Zhang et al., 2009c; Jang et al., 2013). In the State of Aguascalientes in Mexico, this is of great importance because river water is directly used for irrigation and in rural communities as a source of drinking water for livestock. Our results showed that the concentration of coliforms in San Pedro River and its major creeks was exceeding by more than one order of magnitude the WHO tolerance limits (Figure 3). The physicochemical values and microbiological counts found in the San Pedro River are consistent with an important pollution originating from municipal and livestock wastewater (Figures 1, 2). Furthermore, these conditions provide a favorable environment for microbial growth (Figures 2, 3). Given that the water from the San Pedro River is used for irrigation, the water may constitute a source of bacterial contamination that could infect humans or animal through direct contact, aerosol, or consumption of vegetables.

In Mexico, antibiotics are medical drugs with high rate of consumption and their consumption is associated with a high rate of misuse (Dreser et al., 2008). Misuse is caused by unwarranted prescription, inappropriate choice of treatment, self-prescription, lack of adherence by consumers, as well as lax regulation on the use of antibiotics (Zaidi et al., 2003; Amábile-Cuevas et al., 2010). The misuse and overuse of antibiotics is particularly important because it may contribute to selection and increased occurrence of antimicrobial resistant bacteria.

Anthropogenic-driven selective pressures may be contributing to the persistence and dissemination of genes and antimicrobial resistant bacteria usually relevant in clinical environments (Tacão et al., 2012). Our results indicated that samples from industrial and urban runoff sewage had an important presence of antibiotic resistance bacteria (Figure 5). Moreover, the highest number of multi-resistant isolates was found in samples from wastewater discharges from human sewage, industrial sector, and farms. This suggests the importance of wastewater discharges in the dissemination of antimicrobial resistance strains. In the multi-resistant isolates, resistance to FQs such as pefloxacin and levofloxacin was significatively associated with resistance to trimethoprimsulfamethoxazol and ampicillin $(p<0.05)$. This association is likely due to the presence of $q n r$ genes and beta-lactams resistance genes in the multi-resistant isolates (Wang et al., 2001).

At least two thirds of all E. coli isolates were resistant to betalactams such as ampicillin and carbenicillin, and at least one third of the isolates were resistant to trimethoprim-sulfamethoxazole and chloramphenicol (Figure 4). The presence of antibiotic resistant E. coli was also observed in other studies from human and animal fecal sources, wastewater treatment plant and surface water (Sayah et al., 2005; Ibekwe et al., 2011; Mokracka et al., 2011; Sun et al., 2012). Similar resistance levels were found in E. coli isolated from children and adults in Latin America and the 53.2 and $57.7 \%$ isolates were resistant to ampicillin and trimethoprim-sulfamethoxazol, respectively (Estrada-Garcia et al., 2005, 2009).

Most E. coli identified as of pathogenic or potentially pathogenic were classified as intestinal pathogens $(61 \%, 91 / 150)$. EAEC was the most prevalent intestinal pathogenic E. coli $(44 \%$ of the isolates), and this is consistent with previous studies conducted in Mexico (Estrada-Garcia et al., 2005), since in clinical settings, EAEC and ETEC are the most prevalent pathotypes in Mexico (Estrada-Garcia et al., 2005, 2009). Furthermore, several intestinal pathogens with multiple-resistance to antimicrobials were isolated from the River. Thus, the occurrence of pathogenic E. coli with multiple antimicrobial resistances in the San Pedro River represents a great concern due to possible transfer of resistant genes and may increase the probability of infections with a higher cost of treatment.

In our study, most of the isolates resistant to levofloxacin and pefloxacin had a multi-resistant phenotype and some were potentially pathogenic E. coli. Similar results were found in a Mexican study on the prevalence of FQ resistance among E. coli isolates from urinary tract infection (Zaidi et al., 2003; Llanes et al., 2012) as well as from an environmental study (Amábile-Cuevas et al., 2010). In addition, we showed that the triple mutation profile (Ser-83 $\rightarrow$ Leu, Asp-87 $\rightarrow$ Asn in gyrA, and Ser-80 $\rightarrow$ Ile in $\operatorname{par} C$ ) was the most prevalent. The point mutations Ser$83 \rightarrow$ Leu and Asp-87 $\rightarrow$ Asn found in gyrA and Ser-80 $\rightarrow$ Ile in parC, have been observed in other studies (Namboodiri et al., 2011; Sun et al., 2012). Previous studies have shown that E. coli with a single mutation (Ser-83 $\rightarrow$ Leu) in the gyrA subunit are resistant to nalidixic acid, a first generation quinolone (Vila et al., 1994; Sun et al., 2012). In addition, most fluoroquinolone resistance isolates carried horizontally acquired quinolone resistance genes and these were found primarily in combination with QRDR mutations. Qnr proteins may supplement resistance to quinolones due to altered quinolone target enzyme, efflux pump activation, or deficiencies in outer-membrane porins (MartinezMartinez et al., 2003; Poirel et al., 2012). The presence of Qnr determinants facilitates the selection of low-level of resistance to quinolones encoded on the chromosome-encoded and the selection of higher-level resistance mutation (Jacoby, 2005). Several strains that harbored qnrS also carried bla TEM gene. It was reported that, qnrS genes are associated with transposons containing TEM-1 type -lactamases (Hernandez et al., 2011; Dalhoff, 2012). Tetracycline and streptomycin resistance genes were also detected along with FQ resistance genes (Roberts, 2005; Zhang et al., 2009a).

Our results revealed the presence of pathogenic E. coli in the river with present mobile elements as integrons, and multidrug resistance characteristics, including FQ resistance, an antibiotic highly used in humans and animals worldwide, mostly found in locations of the river that have been impacted by industrial sewage and urban runoff. This situation highlights the risk of multidrug resistance pathogens dissemination (Allou et al., 2009; Dalhoff, 2012; Sun et al., 2012). Furthermore, our study was conducted in 
a densely populated area, a setting that is often encountered in developing countries and that must be taken into account (Mazari-Hiriart et al., 2008). This poses a potential risk for human infections because water is used for consumption or for recreation (Maynard et al., 2005; Hamelin et al., 2006, 2007).

The permanent influx of pollutants such as antimicrobial agents, detergents, disinfectants, heavy metals, livestock waste, and watershed may contribute to the emergence of antibiotic resistant bacteria in water as well as the spread of antimicrobial resistance genes and virulence bacteria in San Pedro River. The results show that it is urgent to evaluate the management of wastewater and the water quality in San Pedro River and if necessary, implement a local wastewater treatment to prevent the emergence of infectious outbreaks.

\section{REFERENCES}

Allou, N., Cambau, E., Massias, L., Chau, F., and Fantin, B. (2009). Impact of low-level resistance to fluoroquinolones due to qnrAl and qnrS1 genes or a gyrA mutation on ciprofloxacin bactericidal activity in a murine model of Escherichia coli urinary tract infection. Antimicrob. Agents Chemother. 53, 4292-4297. doi: 10.1128/AAC.01664-08

Amabile-Cuevas, C. F. (2010). Antibiotic resistance in Mexico: a brief overview of the current status and its causes. J. Infect. Dev. Ctries. 4, 126-131. doi: 10.3855/jidc.427

Amábile-Cuevas, C. F., ArredondoGarcia, J. L., Cruz, A., and Rosas, I. (2010). Fluoroquinolone resistance in clinical and environmental isolates of Escherichia coli in Mexico city. J. Appl. Microbiol. 108, 158-162. doi: 10.1111/j.13652672.2009.04401.x

APHA. (1998). APHA-AWWAWEF; Standard Methods for the Examination of Water and Wastewater. 19a Edn. Washington, DC: American Public Health Association.

Aranda, K. R. S., Fabbricotti, S. H., Fagundes-Neto, U., and Scaletsky, I. C. A. (2007). Single multiplex assay to identify simultaneously enteropathogenic, enteroaggregative, enterotoxigenic, enteroinvasive and Shiga toxin-producing Escherichia coli strains in Brazilian children. FEMS Microbiol. Lett. 267, 145-150. doi: 10.1111/j.1574-6968.2006.00580.x

Baquero, F., Martinez, J. L., and Canton, R. (2008). Antibiotics and antibiotic resistance in water environments. Curr. Opin. Biotechnol. 19, 260-265. doi: 10.1016/j.copbio.2008.05.006

Blanco, M., Blanco, J. E., Alonso, M. P., Mora, A., Balsalobre, C., Munoa, F., et al. (1997). Detection of pap, sfa and afa adhesin-encoding operons in uropathogenic Escherichia coli strains: relationship with expression of adhesins and production of toxins. Res. Microbiol. 148, 745-755. doi: 10.1016/S09232508(97)82450-3

Bonnet, C., Diarrassouba, F., Brousseau, R., Masson, L., Topp, E., and Diarra, M. S. (2009). Pathotype and antibiotic resistance gene distributions of Escherichia coli isolates from broiler chickens raised on antimicrobialsupplemented diets. Appl. Environ. Microbiol. 75, 6955-6962. doi: 10.1128/AEM.00375-09

Bruant, G., Maynard, C., Bekal, S., Gaucher, I., Masson, L., Brousseau, R., et al. (2006). Development and validation of an oligonucleotide microarray for detection of multiple virulence and antimicrobial resistance genes in Escherichia coli. Appl. Environ. Microbiol. 72, 3780-3784. doi: 10.1128/AEM.72.5.3780-3784.2006 Jiménez, B. (2011). The removal of microorganisms and organic micropollutants from wastewater during infiltration to aquifers after Valley, Mexico. Environ. Pollut. 159, 2011.01.008

Chen, B., Zheng, W., Yu, Y., Huang, W., Zheng, S., Zhang, Y., et al. (2011). Class 1 integrons, selected virulence genes, and antibiotic resistance in Escherichia coli isolates from the Minjiang River, Fujian Province, China. Appl. Environ. Microbiol. 77, 148-155. doi: 10.1128/AEM. 01676-10

Clermont, O., Bonacorsi, S., and Bingen, E. (2000). Rapid and simple determination of the Escherichia coli phylogenetic group. Appl. Environ. Microbiol. 66, 4555-4558.
Chávez, A., Maya, C., Gibson, R., and irrigation of farmland in the Tula 1354-1462. doi: 10.1016/j.envpol.

\section{ACKNOWLEDGMENTS}

We are thankful to Dr. Ricardo Oropeza for his help in providing genomic DNA controls. We also acknowledge Dr. Yannick D.N. Tremblay for proofreading the manuscript. We thank for her technical assistance to Adriana C. Moreno Flores and Samanta Ramos Flores. We gratefully acknowledge the financial support of the Natural Sciences and Engineering Research Council of Canada (RGPIN-25120) and from-Fonds de la recherché du Québec en Nature et Technologies (Centre de recherche en infectiologie porcine et avicole, CRIPA - Regroupements stratégiques RS-170946) to Josée Harel (RGPIN-25120) and from the DFAIT Canada's Emerging leaders in the Americas program to Alma L. Guerrero Barrera and Josée Harel. Flor Y. Ramírez Castillo is a research scholar of the CONACyT.

doi: $\quad$ 10.1128/AEM.66.10.45554558.2000

CLSI. (2010). Performance Standards for Antimicrobial Susceptibility Testing; Twentieth Information Supplement. M100. S20,30, No. 15. Wayne, PA: Clinical and Laboratory Standards Institute.

Comisión Nacional para el conocimiento y uso de la biodiversidad (CONABIO), Instituto del Medio Ambiente del Estado de Aguascalientes (IMAE), Universidad Autónoma de Aguascalientes (UAA). (2008). "La Biodiversidad en Aguascalientes: Estudio de Estado". Aguascalientes: Comisión Federal para el Conocimiento y Uso de la Biodiversidad.

Czekalski, N., Berthold, T., Caucci, S., Egli, A., and Burgmann, H. (2012). Increased levels of multiresistant bacteria and resistance genes after wastewater treatment and their dissemination into lake Geneva, Switzerland. Front. Microbiol. 3:106. doi: 10.3389/fmicb.2012.00106

Da Silva, G. J., and Mendoça, N. (2012). Association between antimicrobial resistance and virulence in Escherichia coli. Virulence 3, 18-28. doi: 10.4161/viru.3.1.18382

Dalhoff, A. (2012). Global fluoroquinolone resistance epidemiology and implictions for clinical use. Interdiscip. Perspect. Infect. Dis. 2012, 9762-9773. doi: 10.1155/2012/976273

Deguchi, T., Yasuda, M., Nakano, M., Ozeki, S., Kanematsu, E., Nishino, Y., et al. (1997). Detection of mutations in the gyrA and parC genes in quinolone-resistant clinical isolates of Enterobacter cloacae. J. Antimicrob. Chemother. 40, 543-549. doi: 10.1093/jac/40.4.543

Dreser, A., Wirtz, V. J., Corbett, K. K., and Echaniz, G. (2008). Antibiotic use in Mexico: review of problems and policies. Salud Publica Mex. 50, S480-S487. doi: 10.1590/S003636342008001000009

Eaves, D. J., Randall, L., Gray, D. T., Buckley, A., Woodward, M. J., White, A. P., et al. (2004). Prevalence of mutations within the quinolone resistance-determining region of gyrA, gyrB, parC, and parE and association with antibiotic resistance in quinolone-resistant Salmonella enterica. Antimicrob. Agents Chemother. 48, 4012-4015. doi: 10.1128/AAC.48.10.40124015.2004

Estrada-Garcia, T., Cerna, J. F., PahecoGil, L., Velazquez, R. F., Ochoa, T. J., Torres, J., et al. (2005). Drug-resistant diarrheogenic Escherichia coli, Mexico. Emerg. Infect. Dis. 11, 1306-1308. doi: 10.3201/eid1108.050192

Estrada-Garcia, T., Lopez-Saucedo, C., Thompson-Bonilla, R., Abonce, M., Lopez-Hernandez, D., Santos, J. I., et al. (2009). Association of diarrheagenic Escherichia coli pathotypes with infection and diarrhea among Mexican children and association of atypical enteropathogenic E. coli with acute diarrhea. J. Clin. Microbiol. 47, 93-98. doi: 10.1128/JCM.01166-08

Guajardo-Lara, C. E., GonzalezMartinez, P. M., and Ayala-Gaytan, J. J. (2009). [Antibiotic resistance of Escherichia coli from community-acquired urinary tract infections. What antimicrobial to use?]. Salud Publica Mex. 51, 155-159. doi: 10.1590/S003636342009000200012

Gúzman-Colis, G., Thalasso, F. Ramirez-Lopez, E. M., RodriguezNarciso, S., Guerrero-Barrera, A. L., and Avelar-Gonzalez, F. J. (2011). Spatial-temporal evaluation of the water quality of the San Pedro River in Aguascalientes, Mexico. Rev. Int Contam. Ambient 27, 89-102. 
Hamelin, K., Bruant, G., El-Shaarawi, A., Hill, S., Edge, T. A., Bekal, S., et al. (2006). A virulence and antimicrobial resistance DNA microarray detects a high frequency of virulence genes in Escherichia coli isolates from Great Lakes recreational waters. Appl. Environ. Microbiol. 72, 4200-4206. doi: 10.1128/AEM.00137-06

Hamelin, K., Bruant, G., El-Shaarawi, A., Hill, S., Edge, T. A., Fairbrother, J., et al. (2007). Occurrence of virulence and antimicrobial resistance genes in Escherichia coli isolates from different aquatic ecosystems within the St. Clair River and Detroit River areas. Appl. Environ. Microbiol. 73, 477-484. doi: 10.1128/AEM.01445-06

Hansen, L. H., Johannesen, E., Burmolle, M., Sorensen, A. H., and Sorensen, S. J. (2004). Plasmid-encoded multidrug efflux pump conferring resistance to olaquindox in Escherichia coli. Antimicrob. Agents Chemother. 48, 3332-3337. doi: 10.1128/AAC.48.9.3332-3337.2004

Hegstad, K., Langsrud, S., Lunestad, B. T., Scheie, A. A., Sunde, M., and Yazdankhah, S. P. (2010). Does the wide use of quaternary ammonium compounds enhance the selection and spread of antimicrobial resistance and thus threaten our health? Microb. Drug Resist. 16, 91-104. doi: 10.1089/mdr. 2009.0120

Hernandez, A., Sanchez, M. B., and Martinez, J. L. (2011). Quinoloneresistance: much more than predicted. Front. Microbiol. 2:22. doi: 10.3389/fmicb.2011.00022

Hooper, D. C. (2001). Mechanisms of action of antimicrobials: focus on fluoroquinolones. Clin. Infect. Dis. 32(Suppl. 1), S9-S15. doi: $10.1086 / 319370$

Hopkins, K. L., Davies, R. H., and Threlfall, E. J. (2005). Mechanisms of quinolone resistance in Escherichia coli and Salmonella: recent developments. Int. J. Antimicrob. Agents 25, 358-373. doi: 10.1016/j.ijantimicag.2005.02.006

Huang, D. B., Mohamed, J. A., Nataro, J. P., Dupont, H. L., Jiang, Z. D., and Okhuysen, P. C. (2007). Virulence characteristics and the molecular epidemiology of enteroaggregative Escherichia coli isolates from travellers to developing countries. J. Med. Microbiol. 56, 1386-1392. doi: 10.1099/jmm.0.47161-0

Ibekwe, A. M., Murinda, S. E., and Graves, A. K. (2011). Genetic diversity and antimicrobial resistance of Escherichia coli from human and animal sources uncovers multiple resistances from human sources. PLoS ONE 6:e20819. doi: 10.1371/journal.pone.0020819

Jacoby, G. A. (2005). Mechanisms of resistance to quinolones. Clin. Infect. Dis. 41(Suppl. 2), S120-S126. doi: $10.1086 / 428052$

Jacoby, G. A., Chow, N., and Waites, K. B. (2003). Prevalence of plasmid-mediated quinolone resistance. Antimicrob. Agents Chemother. 47, 559-562. doi: 10.1128/AAC.47.2.559-562.2003

Jakobsen, L., Garneau, P., Kurbasic, A., Bruant, G., Stegger, M., Harel, J., et al. (2011). Microarray-based detection of extended virulence and antimicrobial resistance gene profiles in phylogroup B2 Escherichia coli of human, meat and animal origin. J. Med. Microbiol. 60, 1502-1511. doi: 10.1099/jmm.0.033993-0

Jang, J., Suh, Y. S., Di, D. Y., Unno, T., Sadowsky, M. J., and Hur, H. G. (2013). Pathogenic Escherichia coli strains producing extendedspectrum beta-lactamases in the Yeongsan River basin of South Korea. Environ. Sci. Technol. 47, 1128-1136. doi: 10.1021/es303577u Johnson, J. R., and Stell, A. L. (2000). Extended virulence genotypes of Escherichia coli strains from patients with urosepsis in relation to phylogeny and host compromise. J. Infect. Dis. 181, 261-272. doi: $10.1086 / 315217$

Kaper, J. B., Nataro, J. P., and Mobley, H. L. (2004). Pathogenic Escherichia coli. Nat. Rev. Microbiol. 2, 123-140. doi: 10.1038/nrmicro818

Koczura, R., Mokracka, J., Jablonska, L., Gozdecka, E., Kubek, M., and Kaznowski, A. (2012). Antimicrobial resistance of integron-harboring Escherichia coli isolates from clinical samples, wastewater treatment plant and river water. Sci. Total Environ. 414, 680-685. doi: 10.1016/j.scitotenv.2011.10.036

Kümmerer, K. (2004). Resistance in the environment. J. Antimicrob. Chemother. 54, 311-320. doi: 10.1093/jac/dkh325

Kümmerer, K. (2009a). Antibiotics in the aquatic environment-a reviewpart I. Chemosphere 75, 417-434. doi: 10.1016/j.chemosphere.2008. 11.086

Kümmerer, K. (2009b). Antibiotics in the aquatic environment-a reviewpart II. Chemosphere 75, 435-441. doi: 10.1016/j.chemosphere.2008. 12.006

Llanes, J. M., Varon, J., Felix, J. S. V., and Gonzalez-Ibarra, F. P.
(2012). Antimicrobial resistance of Escherichia coli in Mexico: how serious is the problem? J. Infec. Dev. Ctries. 6, 126-131. doi: 10.3855/jidc. 1525

Lupo, A., Coyne, S., and Berendonk, T. U. (2012). Origin and evolution of antibiotic resistance: the common mechanisms of emergence and spread in water bodies. Front. Microbiol. 3:18. doi: 10.3389/fmicb.2012.00018

McArthur, J. V., and Tuckfield, R. C. (2000). Spatial patterns in antibiotic resistance among stream bacteria: effects of industrial pollution. Appl. Environ. Microbiol. 66, 3722-3726. doi 10.1128/AEM.66.9.3722-3726.2000

Martinez, J. L. (2009). The role of natural environments in the evolution of resistance traits in pathogenic bacteria. Proc. Biol. Sci. 276, 2521-2530. doi: 10.1098/rspb.2009.0320

Martinez-Martinez, L., Pascual, A. Garcia, I., Tran, J., and Jacoby, G. A. (2003). Interaction of plasmid and host quinolone resistance. J. Antimicrob. Chemother. 51 1037-1039. doi: 10.1093/jac/dkg157

Martinez-Martinez, L., Pascual, A., and Jacoby, G. A. (1998). Quinolone resistance from a transferable plasmid. Lancet 351, 797-799. doi 10.1016/S0140-6736(97)07322-4

Maynard, C., Berthiaume, F. Lemarchand, K., Harel, J., Payment, P., Bayardelle, P., et al. (2005) Waterborne pathogen detection by use of oligonucleotide-based microarrays. Appl. Environ. Microbiol. $\quad 71, \quad 8548-8557$. doi: $\quad 10.1128 /$ AEM.71.12.85488557.2005

Maynard, C., Bekal, S., Sanschagrin, F., Levesque, R. C., Brousseau, R., Masson, L., et al. (2004). Heterogeneity among virulence and antimicrobial resistance gene profiles of extraintestinal Escherichia coli isolates of animal and human origin. J. Clin. Microbiol. 42, 5444-5452. doi: 10.1128/JCM.42.12.5444-5452.2004

Mazari-Hiriart, M., Ponce-De-Leon, S. Lopez-Vidal, Y., Islas-Macias, P., Amieva-Fernandez, R I., and Quinones-Falconi, F (2008). Microbiological implications of periurban agriculture and water reuse in Mexico City. PLoS ONE 3:e2305. doi: 10.1371/journal.pone.0002305

Mokracka, J., Koczura, R., Jablonska, L., and Kaznowski, A. (2011). Phylogenetic groups, virulence genes and quinolone resistance of integron-bearing Escherichia coli strains isolated from a wastewater treatment plant. Antonie Van Leeuwenhoek 99, 817-824. doi: 10.1007/s10482-011-9555-4

Namboodiri, S. S., Opintan, J. A., Lijek, R. S., Newman, M. J., and Okeke, I. N. (2011). Quinolone resistance in Escherichia coli from Accra, Ghana. BMC Microbiol. 11:44. doi 10.1186/1471-2180-11-44

Nataro, J. P., and Kaper, J. B. (1998). Diarrheagenic Escherichia coli. Clin. Microbiol. Rev. 11, 142-201.

Park, C. H., Robicsek, A., Jacoby, G. A., Sahm, D., and Hooper, D. C. (2006). Prevalence in the United States of aac $\left(6^{\prime}\right)-\mathrm{Ib}-\mathrm{cr}$ encoding a ciprofloxacin-modifying enzyme. Antimicrob. Agents Chemother. 50, 3953-3955. doi: 10.1128/AAC.00915-06

Poirel, L., Cattoir, V., and Nordmann, P. (2012). Plasmid-mediated quinolone resistance; interactions between human, animal, and environmental ecologies. Front. Microbiol. 3:24. doi 10.3389/fmicb.2012.00024

Pruden, A., Pei, R., Storteboom, H., and Carlson, K. H. (2006). Antibiotic resistance genes as emerging contaminants: studies in northern Colorado. Environ Sci. Technol. 40, 7445-7450. doi 10.1021/es0604131

Roberts, M. C. (2005). Update on acquired tetracycline resistance genes. FEMS Microbiol. Lett. 245, 195-203. doi: 10.1016/j.femsle.2005.02.034

Robicsek, A., Strahilevitz, J., Jacoby, G. A., Macielag, M., Abbanat, D., Park, C. H., et al. (2006a). Fluoroquinolone-modifying enzyme: a new adaptation of a common aminoglycoside acetyltransferase. Nat. Med. 12, 83-88. doi: $10.1038 / \mathrm{nm} 1347$

Robicsek, A., Strahilevitz, J., Sahm, D. F., Jacoby, G. A., and Hooper, D. C. (2006b). qnr prevalence in ceftazidime-resistant Enterobacteriaceae isolates from the United States. Antimicrob. Agents Chemother. 50, 2872-2874. doi: 10.1128/AAC.01647-05

Roe, M. T., Vega, E., and Pillai, S. D. (2003). Antimicrobial resistance markers of class 1 and class 2 integron-bearing Escherichia coli from irrigation water and sediments. Emerg. Infect. Dis. 9, 822-826. doi: 10.3201/eid0907.020529

Salem, I. B., Ouardani, I., Hassine, M., and Aouni, M. (2011). Bacteriological and physicochemical assessment of wastewater in different region of Tunisia: impact on human health. 
BMC Res. Notes 4:144. doi: 10.1186/1756-0500-4-144

Sayah, R. S., Kaneene, J. B., Johnson, Y., and Miller, R. (2005). Patterns of antimicrobial resistance observed in Escherichia coli isolates obtained from domestic- and wild-animal fecal samples, human septage, and surface water. Appl. Environ. Microbiol. 71, 1394-1404. doi: 10.1128/AEM.71.3.1394-1404.2005

Sun, J., Hu, J., Peng, H., Shi, J., and Dong, Z. (2012). Molecular and physiological characterization of fluoroquinolone resistance in relation to uropathogenicity among Escherichia coli isolates isolated from Wenyu River, China. Chemosphere 87, 37-42. doi: 10.1016/j.chemosphere.2011.11.050

Suzuki, S., and Hoa, P. T. (2012). Distribution of quinolones, sulfonamides, tetracyclines in aquatic environment and antibiotic resistance in indochina. Front. Microbiol. 3:67. doi: 10.3389/fmicb. 2012.00067

Tacão, M., Correia, A., and Henriques, I. (2012). Resistance to broadspectrum antibiotics in aquatic systems: anthropogenic activities modulate the dissemination of bla(CTX-M)-like genes. Appl. Environ. Microbiol. 78, 4134-4140. doi: 10.1128/AEM.00359-12

Toma, C., Lu, Y., Higa, N., Nakasone, N., Chinen, I., Baschkier, A., et al. (2003). Multiplex PCR assay for identification of human diarrheagenic Escherichia coli. J. Clin. Microbiol. 41, 2669-2671. doi: 10.1128/JCM.41.6.2669-2671.2003
Tran, J. H., Jacoby, G. A., and Hooper, D. C. (2005a). Interaction of the plasmid-encoded quinolone resistance protein Qnr with Escherichia coli DNA gyrase. Antimicrob. Agents Chemother. 49, 118-125. doi: 10.1128/AAC.49.1.118-125.2005

Tran, J. H., Jacoby, G. A., and Hooper, D. C. (2005b). Interaction of the plasmid-encoded quinolone resistance protein QnrA with Escherichia coli topoisomerase IV. Antimicrob. Agents Chemother. 49, 3050-3052. doi: 10.1128/AAC.49.7.3050-3052.2005

Vila, J., Ruiz, J., Marco, F., Barcelo, A., Goni, P., Giralt, E., et al. (1994). Association between double mutation in gyrA gene of ciprofloxacin-resistant clinical isolates of Escherichia coli and MICs. Antimicrob. Agents Chemother. 38, 2477-2479. doi: 10.1128/AAC. 38.10 .2477

Vila, J., Vargas, M., Henderson, I. R., Gascon, J., and Nataro, J. P. (2000). Enteroaggregative Escherichia coli virulence factors in traveler's diarrhea strains. J. Infect. Dis. 182, 1780-1783. doi: 10.1086/317617

Wang, H., Dzink-Fox, J. L., Chen, M., and Levy, S. B. (2001). Genetic characterization of highly fluoroquinolone-resistant clinical Escherichia coli strains from China: role of acrR mutations. Antimicrob. Agents Chemother. 45, 1515-1521. doi: 10.1128/AAC.45.5.1515-1521.2001

West, B. M., Liggit, P., Clemans, D. L., Francoeur, S. N. (2011). Antibiotic resistance, gene transfer, and water quality patterns observed in waterways near CAFO farms and wastewater treatment facilities. Water Air Soil Pollut. 217, 473-489. doi: 10.1007/s11270-0100602-y

WHO. (2006). Guidelines for the Safe use of Wastewater, Excreta and Greywater. Geneva: World Health Organization.

Yamane, K., Wachino, J., Suzuki, S., Kimura, K., Shibata, N., Kato, H., et al. (2007). New plasmid-mediated fluoroquinolone efflux pump, QepA, found in an Escherichia coli clinical isolate. Antimicrob. Agents Chemother. 51, 3354-3360. doi: 10.1128/AAC.00339-07

Zaidi, M. B., Zamora, E., Diaz, P., Tollefson, L., Fedorka-Cray, P. J., and Headrick, M. L. (2003). Risk factors for fecal quinoloneresistant Escherichia coli in Mexican children. Antimicrob. Agents Chemother. 47, 1999-2001. doi: 10.1128/AAC.47.6.1999-2001.2003

Zhang, X., Wu, B., Zhang, Y., Zhang, T., Yang, L., Fang, H. H., Ford, T., and Cheng, S. (2009a). Class 1 integronase gene and tetracycline resistance genes tet $\mathrm{A}$ and tet $\mathrm{C}$ in different water environments of Jiangsu Province, China. Ecotoxicology 18, 652-660. doi: 10.1007/s10646-0090332-3

Zhang, X. X., Zhang, T., and Fang, H. (2009b). Antibiotic resistance genes in water environment. Appl. Microbiol. Biotechnol. 82, 397-414. doi: 10.1007/s00253-008-1829-z

Zhang, Y. L., Marrs, C. F., Simon, C., and Xi, C. W. (2009c). Wastewater treatment contributes to selective increase of antibiotic resistance among Acinetobacter spp. Sci. Total Environ. 407, 3702-3706. doi: 10.1016/j.scitotenv.2009.02.013

Conflict of Interest Statement: The authors declare that the research was conducted in the absence of any commercial or financial relationships that could be construed as a potential conflict of interest.

Received: 22 March 2013; accepted: 25 May 2013; published online: 17 June 2013.

Citation: Ramírez Castillo FY, Avelar González FJ, Garneau P, Márquez Díaz F, Guerrero Barrera $A L$ and Harel J (2013) Presence of multi-drug resistant pathogenic Escherichia coli in the San Pedro River located in the State of Aguascalientes, Mexico. Front. Microbiol. 4:147. doi: 10.3389/ fmicb.2013.00147

This article was submitted to Frontiers in Antimicrobials, Resistance and Chemotherapy, a specialty of Frontiers in Microbiology.

Copyright (c) 2013 Ramírez Castillo, Avelar González, Garneau, Márquez Díaz, Guerrero Barrera and Harel. This is an open-access article distributed under the terms of the Creative Commons Attribution License, which permits use, distribution and reproduction in other forums, provided the original authors and source are credited and subject to any copyright notices concerning any third-party graphics etc. 


\section{APPENDIX}

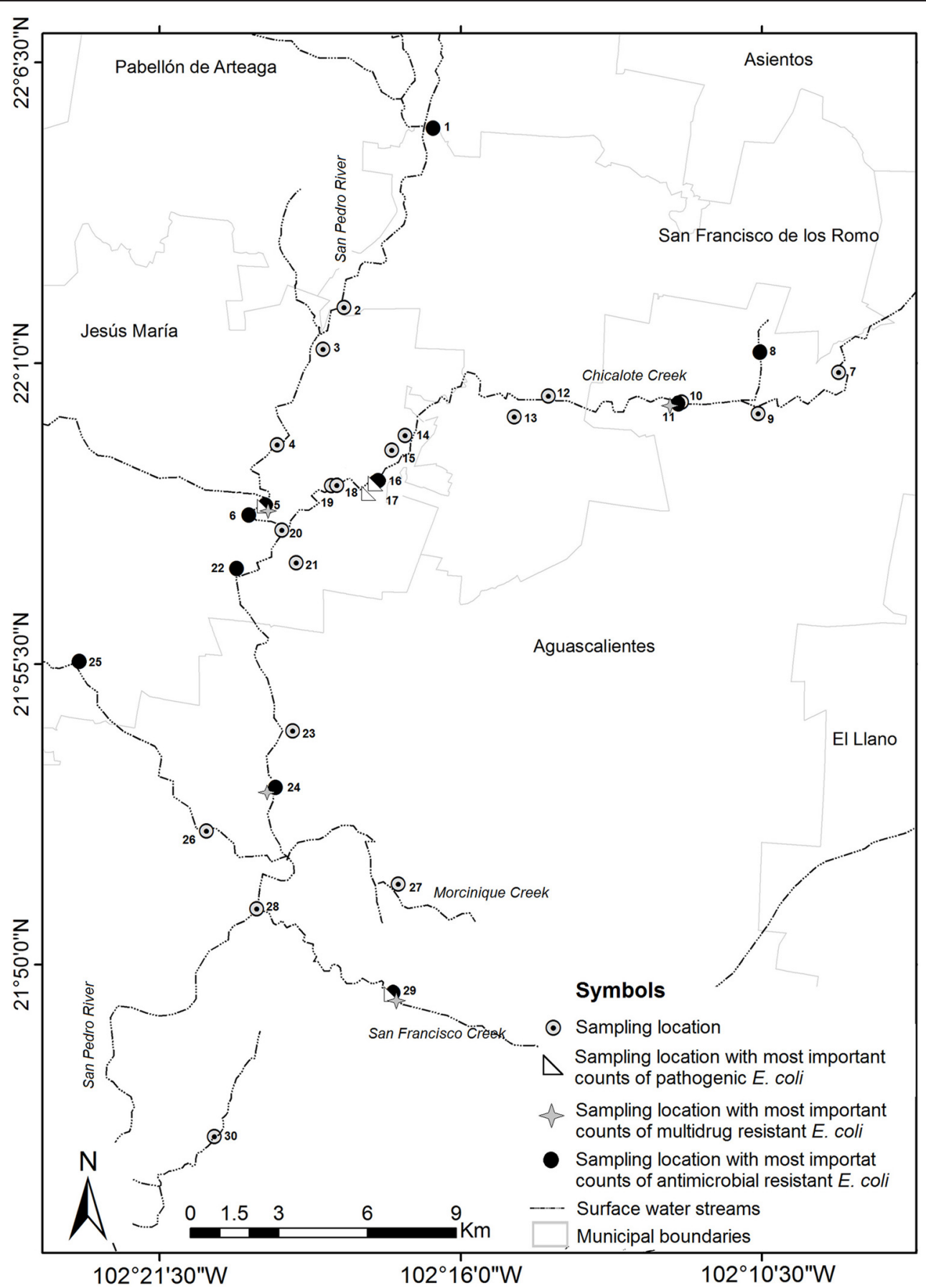

FIGURE A1 | Diagram showing the highest levels of pollution, highest counts of the pathotype, and antimicrobial resistant bacteria of the sample locations studied. 